\title{
POLA DISTRIBUSI TDS DI TIGA LOKASI SUNGAI SEGMEN CIMAHI-BANDUNG UTARA DAN PERKIRAAN \\ SUMBERNYA
}

\author{
TESIS \\ Karya tulis sebagai salah satu syarat \\ untuk memperoleh gelar Magister dari \\ Institut Teknologi Bandung
}

\author{
Oleh \\ SRI ADITYA \\ NIM: 22715303 \\ (Program Studi Magister Teknik Air Tanah)
}

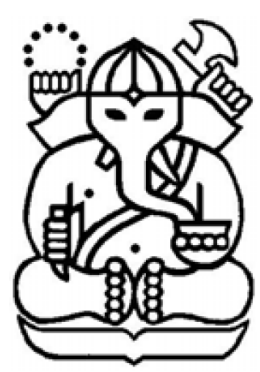

INSTITUT TEKNOLOGI BANDUNG

Maret 2018 


\title{
ABSTRAK \\ Pola distribusi TDS di tiga lokasi sungai segmen Cimahi-Bandung Utara dan perkiraan sumbernya
}

\author{
Oleh \\ Sri Aditya \\ NIM: 22715303 \\ (Program Studi Magister Teknik Air Tanah)
}

\begin{abstract}
Variasi harian data kualitas air dapat dianalisis untuk mengetahui proses yang terjadi pada air sungai itu sendiri juga interaksinya dengan air tanah, khusus pada zona hyporheic. Observasi dilakukan di tiga lokasi anak Sungai Cikapundung di tahun 2017 (periode Maret-November 2017). Pengukuran dilakukan pada tiga lokasi di DAS S. Cikapundung (diurutkan dari utara-selatan): S. Ciawitali lokasi Curug Panganten (CP) dan Grand Royal Pancanaka (GRP), S. Cibeureum lokasi Pondok Hijau Indah (PHI). Tata guna lahan berevolusi dari lahan terbuka berupa hutan dan lahan perkebunan/pertanian di lokasi CP dan GRP, ke perumahan di PHI. Sungai di ketiga lokasi itu menjadi muara dari saluran-saluran air yang melewati kawasan di tepi kiri dan kanannya.
\end{abstract}

Pengukuran debit (meter/detik), temperatur air sungai (derajat Celcius), temperatur udara (derajat Celcius), dan TDS (total dissolved solids) (ppm). Pengukuran dilakukan dengan alat portabel merk Lutron, masing-masing dengan ketelitian 0.01 pada masing-masing satuan yang berkaitan. Pengukuran dilakukan empat kali di masing-masing lokasi: pukul 10.00, 12.00, 14.00, dan 16.00. Data kemudian dianalisis menggunakan piranti lunak open source $\mathrm{R}$ untuk teknik time series.

Hasil pengukuran di ketiga lokasi tersebut menunjukkan variasi mingguan dan bulanan. Untuk variasi minggu, nilai TDS naik mulai hari Jumat dan turun pada hari Senin. Lokasi yang paling konsisten menunjukkan gejala ini adalah PHI. Variasi bulanan menunjukkan peningkatan di bulan Juni dan turun di bulan Juli. Pola ini terjadi di tiga lokasi tersebut. Pada titik ini, kami berpendapat bahwa pola tersebut diduga berkaitan dengan aktivitas manusia yang meningkat di akhir minggu. Untuk pola bulanan, ada indikasi bahwa peningkatan TDS bersamaan dengan liburan Lebaran 2017. Dugaan tersebut perlu diklarifikasi lebih lanjut dengan pengukuran kandungan nutrien (nitrat, nitrit, fosfat, klorin, dan sulfat) secara time series. Dari riset ini, dapat kami sampaikan bahwa data time series sangat berperan dalam analisis lingkungan, sehingga layak untuk dikembangkan.

Keywords: Cikapundung, Bandung, Total Dissolved Solids, Kualitas Air, Time Series, interaksi air tanah dan air permukaan/air sungai 


\section{ABSTRACT \\ The distribution pattern of TDS at three river locations in segment Cimahi-Northern Bandung and its estimated sources \\ by \\ Sri Aditya \\ NIM: 22715303 \\ (Magister Program in Groundwater Engineering)}

Many processes can influence river water and groundwater to its current form. Daily variation of water quality data can be analyzed to understand such processes. This research mainly analyzed time series data of TDS from river water to understand the processes. We suspect that local drainage has a strong influence to the increasing values of TDS in the river water. We collected the data from March to November 2017 at three locations (from north to south): S. Ciawitali located at Curug Panganten (CP) and at Grand Royal Pancanaka (GRP), and S. Cibeureum located at Pondok Hijau Indah (PHI). At each locations we measured air temperature, river water temperature, and TDS. The measurements were conducted four times/day, 3 days/week in eight months. To support our claims, we also analyzed 310 water quality dataset that were available to classify the samples. We used open source applications, R, to produce the calculation and the plots. From the three locations, we find that TDs values on CP and PHI show a cyclic weekly pattern, with the values from PHI are averagely $20 \%$ higher than values from $\mathrm{CP}$ at given period. We don't find the same pattern at GRP. The values from that location show a random pattern. Interestingly, we find an increasing trend from June to July. We argue that the cyclic pattern at $\mathrm{CP}$ and PHI are brought by many drainage outlets in the river bank. Such drainage collects domestic waste from housings and nearby accommodations (hotels) and tourist objects. Both locations are known as part of tourist object area at northern Bandung. GRP does not show the same situation because the TDS most likely only from the nearby GRP housing. The observation site is located at a man made channel that connect two natural channel through GRP housing complex. We argue that the TDS values at the channel capture a closed system drainage, compare to the open system at CP and PHI. Based on the multivariable analysis, we also see a close interaction between groundwater and river water at various places in Bandung area. This phenomenon should add our understanding on the patterns of TDS value. Such close interactions between groundwater and river water, should be the focus of the Bandung authorities. In this such close interactions, the contamination present in the river environment could come both from the river and the groundwater system. Both water have the same chance to send out man-made pollution in the environment.

Keywords: Cikapundung, Bandung, Total Dissolved Solids, Water Quality, Time Series, Groundwater and Surface/River Water Interactions 
Pola distribusi TDS di tiga lokasi sungai segmen Cimahi-Bandung Utara dan perkiraan sumbernya

\author{
Oleh \\ Sri Aditya \\ NIM: 22715303 \\ (Program Studi Magister Teknik Air Tanah)
}

Institut Teknologi Bandung

Menyetujui

Pembimbing

Ketua

Anggota

Tanggal 8 Maret 2018

(Dr. Dasapta Erwin Irawan)

(.)

Anggota

Anggota

(.)

(.) 
Dipersembahkan untuk orang tua ku 


\section{PEDOMAN PENGGUNAAN TESIS}

Tesis Magister ini tersedia di Perpustakaan Institut Teknologi Bandung dan terbuka untuk umum dengan ketentuan bahwa hak cipta ada pada penulis dengan mengikuti aturan HaKI yang berlaku di Institut Teknologi Bandung.

Referensi kepustakaan diperkenankan dicatat, tetapi pengutipan atau peringkasan harus disertai dengan kaidah ilmiah untuk menyebutkan sumbernya.

Sitasi hasil penelitian Disertasi ini dapat ditulis dalam bahasa Indonesia sebagai berikut:

Aditya, S. (2018): Pola distribusi temperatur, TDS, dan pH asir di tiga anak Sungai Cikapundung, Bandung, Tesis Program Magister, Institut Teknologi Bandung.

dan dalam bahasa Inggris sebagai berikut:

Aditya, S. (2018): The distribution pattern of water temperature, TDS, pH at three substreams of Cikapundung River, Master Thesis, Institut Teknologi Bandung.

Memperbanyak atau menerbitkan sebagian atau seluruh disertasi haruslah seizin Dekan Sekolah Pascasarjana, Institut Teknologi Bandung. 


\section{KATA PENGANTAR}

Banyak hal baru yang didapatkan oleh penulis dari tugas akhir ini. Untuk itu, penulis sangat berterima kasih kepada Dr. Dasapta Erwin Irawan selaku pembimbing dan Prof.Dr. Deny Juanda Puradimaja yang telah memberikan banyak masukan selama penelitian berlangsung. Tidak lupa penulis juga mengucapkan terima kasih bagi rekan-rekan yang telah memberikan beberapa masukan melalui media sosial.

Terima kasih disampaikan juga kepada rekan-rekan Program Sarjana Teknik Geologi yang telah meluangkan waktu membantu pengambilan data di lapangan.

Bandung, Maret 2018

Penulis 


\section{DAFTAR ISI}

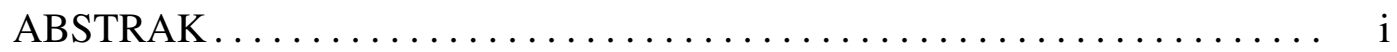

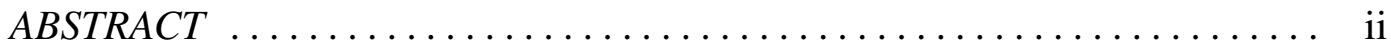

HALAMAN PENGESAHAN $\ldots \ldots \ldots \ldots \ldots \ldots \ldots \ldots \ldots \ldots \ldots \ldots$ iii

HALAMAN PERUNTUKAN $\ldots \ldots \ldots \ldots \ldots \ldots \ldots \ldots \ldots \ldots \ldots \ldots$ iv

PEDOMAN PENGGUNAAN TESIS $\ldots \ldots \ldots \ldots \ldots \ldots \ldots \ldots \ldots \ldots \ldots$ v

KATA PENGANTAR $\ldots \ldots \ldots \ldots \ldots \ldots \ldots \ldots \ldots \ldots \ldots \ldots \ldots \ldots \ldots \ldots \ldots \ldots$

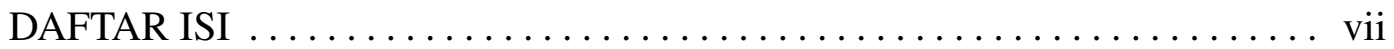

DAFTAR GAMBAR $\ldots \ldots \ldots \ldots \ldots \ldots \ldots \ldots \ldots \ldots \ldots \ldots \ldots \ldots \ldots \ldots \ldots \ldots$

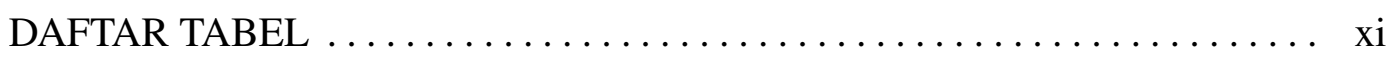

DAFTAR LAMBANG $\ldots \ldots \ldots \ldots \ldots \ldots \ldots \ldots \ldots \ldots \ldots \ldots \ldots \ldots \ldots$

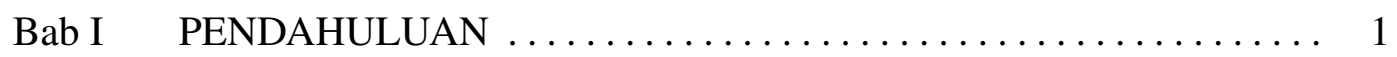

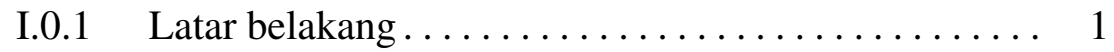

I.0.2 Masalah yang dikaji $\ldots \ldots \ldots \ldots \ldots \ldots \ldots \ldots . \ldots \ldots$

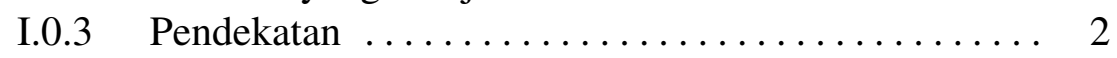

I.0.4 Sistematika pembahasan $\ldots \ldots \ldots \ldots \ldots \ldots \ldots . \ldots$

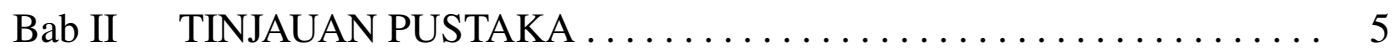

II.0.1 Telaah bibliometrik ................ 5

II.0.2 Total dissolved solids/Zat padat terlarut ......... 7

II.0.3 Suhu air dan suhu udara . . . . . . . . . . . . . . . 9

II.0.4 Terkait analisis $\ldots \ldots \ldots \ldots \ldots \ldots \ldots \ldots$

Bab III METODE PENELITIAN $\ldots \ldots \ldots \ldots \ldots \ldots \ldots \ldots \ldots \ldots \ldots \ldots \ldots$

III.0.1 Jenis riset $\ldots \ldots \ldots \ldots \ldots \ldots \ldots \ldots \ldots \ldots \ldots \ldots \ldots \ldots$

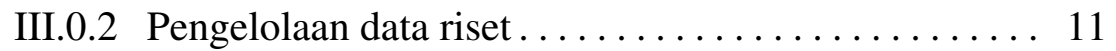

III.0.3 Uraian data ....................... 13

III.0.4 Analisis time series .................... 14

III.0.5 Analisis multivariabel............... 14

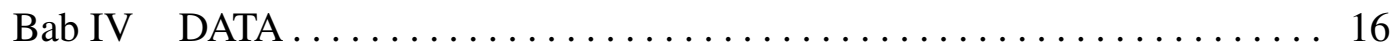

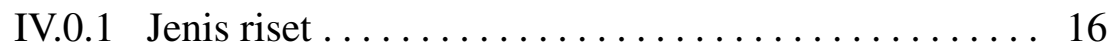

IV.0.2 Pengelolaan data ..................... 16

IV.0.3 Uraian data $\ldots \ldots \ldots \ldots \ldots \ldots \ldots \ldots \ldots \ldots$

Bab V HASIL DAN PEMBAHASAN . . . . . . . . . . . . . . . 18

V.0.1 Temperatur udara dan temperatur air sungai ...... 18

V.0.2 TDS .......................... 19

V.0.3 Analisis multivariabel................ 23

Bab VI KESIMPULAN DAN SARAN .................... 28

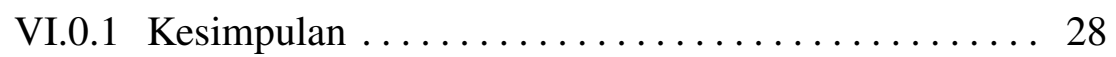

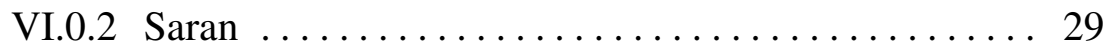




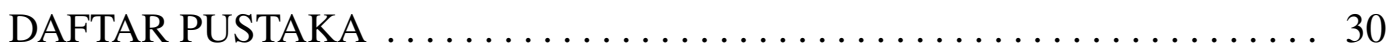

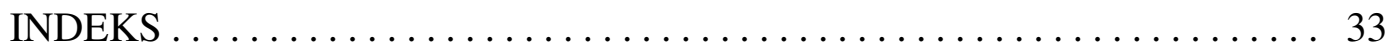




\section{DAFTAR GAMBAR}

Gambar I.1 Titik pembuangan limbah rumah tangga ke aliran Sungai Cibeureum yang berukuran besar ............. 1

Gambar I.2 Beberapa titik pembuangan limbah rumah tangga ke aliran Sungai Cikapundung berukuran kecil-kecil ...... 2

Gambar I.3 Tiga lokasi observasi ................... 3

Gambar II.1 Jejaring kata kunci dalam lingkup riset bertema interaksi antara air tanah dan air permukaan/air sungai ........ 5

Gambar II.2 Jejaring penulis dalam lingkup riset bertema interaksi antara air tanah dan air permukaan/air sungai ......... 6

Gambar II.3 Jejaring kata kunci artikel bertema hidrologi/hidrogeologi Indonesia .................... 7

Gambar II.4 Jejaring penulis dalam lingkup riset bertema hidrologi/hidrogeologi Indonesia . . . ......... 7

Gambar II.5 Model peningkatan TDS sebagai salah satu indikator penurunan kualitas lingkungan hidup $\ldots \ldots \ldots \ldots \ldots .8$

Gambar II.6 Model alur peningkatan TDS dari hulu ke hilir . . . . . . . 8

Gambar II.7 Struktur analisis dalam riset $\ldots \ldots \ldots \ldots \ldots \ldots \ldots \ldots$

Gambar II.8 Analisis time series, PCA dan CA untuk memperbaiki interpretasi visual ...................... 10

Gambar III.1 Alur pikir riset eksploratori berdasarkan prinsip data science .......................... 11

Gambar III.2 Struktur folder dan data riset dalam spesifikasi Project TIER 12

Gambar III.3 Struktur repositori dan penyimpanan berkas riset... . . . . . 13

Gambar III.4 Ilustrasi proses dekomposisi data time series . . . . . . . . 14

Gambar V.1 Plot temperatur udara (biru) dan temperatur sungai (merah) di lokasi CP. .................. 18

Gambar V.2 Klasifikasi air berdasarkan nilai TDS (Premier Water Minnesota) ................................ 19

Gambar V.3 Plot histogram TDS di lokasi CP (atas), PHI (tengah), dan GRP (bawah) ........................ 20

Gambar V.4 Plot time series TDS di lokasi CP (atas), PHI (tengah), dan GRP (bawah). ...................... 21

Gambar V.5 Plot time series TDS dalam satu plot untuk memudahkan melihat kisaran angka (abu: GRP, biru: PHI, dan merah

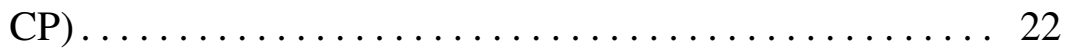

Gambar V.6 Analisis dekomposisi data TDS di lokasi CP ........ 22

Gambar V.7 Analisis dekomposisi data TDS di lokasi PHI . . . . . . . 23

Gambar V.8 Analisis dekomposisi data TDS di lokasi GRP . . . . . . . . 23

Gambar V.9 Analisis aktivitas obyek wisata dan perekonomian di lokasi CP (atas), PHI (tengah), dan GRP (bawah) ...... 24

Gambar V.10 Nilai variabel terhadap komponen prinsipal (Loading PCA) 25

Gambar V.11 Posisi sampel terhadap komponen prinsipal (Scores PCA)

(Merah=airtanah, biru=air sungai) $\ldots \ldots \ldots \ldots \ldots \ldots 26$ 
Gambar V.12 Jumlah klaster optimal berdasarkan metode Kmeans . . . . . 27

Gambar V.13 Penggolongan sampel menggunakan klaster metode

Kmeans ............................ 27 


\section{DAFTAR TABEL}

Tabel III.1 Variabel yang diukur di lapangan . . . . . . . . . . . . . . 13

Tabel IV.1 Variabel yang diukur di lapangan ............... 16 


\section{Bab I PENDAHULUAN}

\section{I.0.1 Latar belakang}

Sungai merupakan komponen penting bagi kehidupan dan dalam kehidupan manusia. Fungsi utama sungai di wilayah Cekungan Bandung saat ini adalah sebagai sumber air untuk pengairan lahan pertanian, rumah tangga, dan industri. Kelestarian lingkungan sungai (meliputi aspek biogeofisik) dapat menurun kualitasnya sejalan dengan penurunan kualitas air. Gejalanya dapat diamati dengan mudah, misalnya: bau busuk air, warna air yang hitam, keruh, yang ditambah dengan efeknya kepada kesehatan. Penyakit kulit dan pencernaan (khususnya diare) adalah yang paling banyak diderita masyarakat akibat lingkungan air yang tercemar, akibat sistem sanitasi yang buruk (Rohmat, 2009; Marganingrum dkk., 2013; Astuti, 2013). Pada banyak lokasi, air kotor dari pemukiman, industri, serta limbah pertanian dibuang langsung ke sungai utama (Gambar I.1). Banyak juga outlet berukuran kecil yang kami dapati di lapangan (Gambar I.2). Kondisi ini merupakan hal yang menarik untuk ditelaah menggunakan analisis time series dan multivariabel.

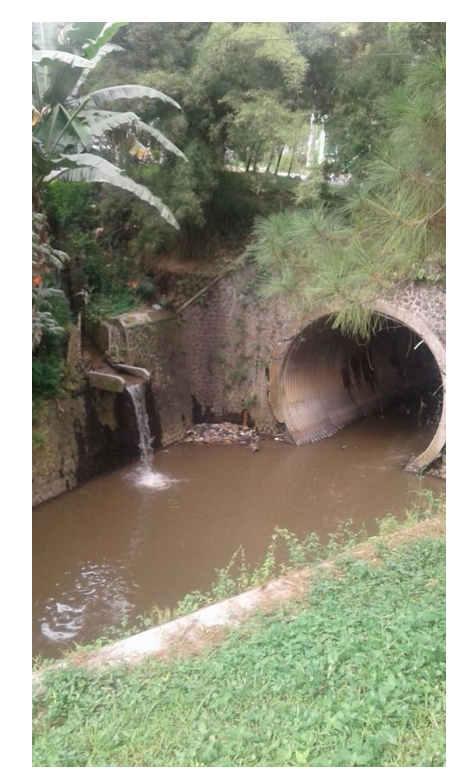

Gambar I.1 Titik pembuangan limbah rumah tangga ke aliran Sungai Cibeureum yang berukuran besar 


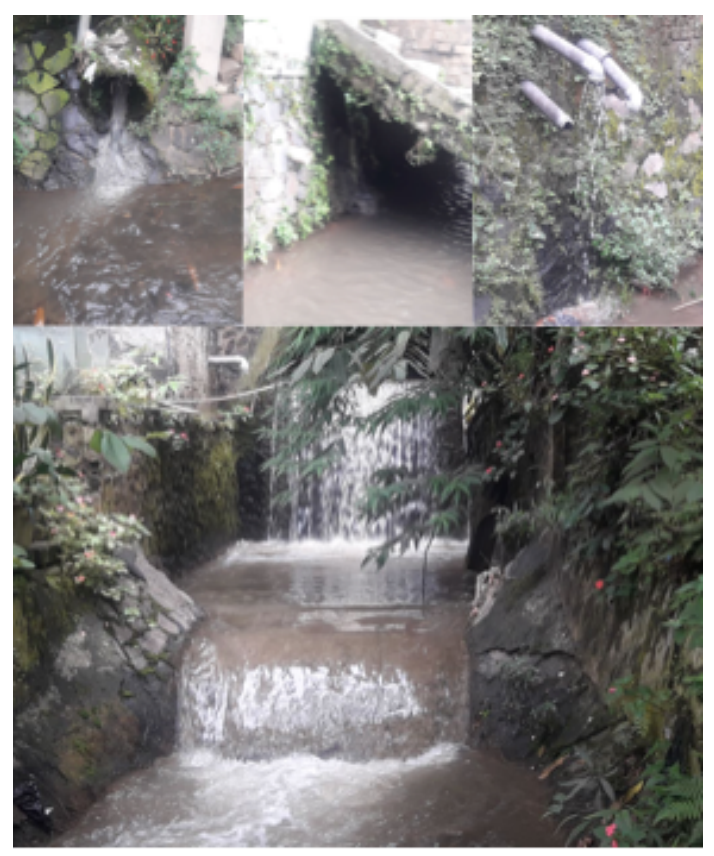

Gambar I.2 Beberapa titik pembuangan limbah rumah tangga ke aliran Sungai Cikapundung berukuran kecil-kecil

\section{I.0.2 Masalah yang dikaji}

Beberapa penelitian saat ini telah mengetahui zonasi interaksi antara air tanah dan air Sungai Cikapundung dan kedekatan diantara kedua tubuh air tersebut (Darul dkk., 2016; Tanuwijaya dkk., 2017). Kami tertarik untuk mengetahui fluktuasi harian dan bulanan beberapa parameter air, yang terdiri dari: temperatur air, temperatur udara, total dissolved solids (TDS), kelembaban udara, untuk mencari korelasinya dengan kondisi lingkungan di sekitarnya. Hipotesis kami adalah, bahwa TDS sebagai salah satu indikasi pencemaran yang dapat diukur dengan alat yang murah akan berkorelasi dengan tata guna lahan di sekitarnya. Untuk itu kami memilih tiga wilayah yang menjadi target penelitian diantaranya Curug Panganten (CP), Grand Royal Pancanaka (GRP) (Sungai Ciawitali) dan Perumahan Pondok Hijau Indah (PHI) (Sungai Cibeureum) (lokasi lihat Gambar I.3). Lokasi CP dipilih untuk merepresentasikan wilayah yang masih natural, lokasi GRP mewakili wilayah dengan lahan pesawahan, serta PHI untuk wilayah perumahan. Ketiganya diharapkan mampu menunjukkan karakter yang berbeda-beda.

\section{I.0.3 Pendekatan}

Dalam penelitian ini, kami mengumpulkan data secara time series (kohort) dan analisis multivariabel menggunakan metode Analisis Komponen Prinsipal 
(Principal Component Analysis, selanjutkan kami sebut PCA) dan Analisis Klaster (Cluster Analysis, selanjutnya kami sebut CA). Berikut rinciannya:

- Analisis time series: Pada setiap titik dilakukan pengukuran temperatur air dan temperatur udara, TDS, dan kelembaban udara dengan frekuensi empat kali per hari, seminggu dua kali, selama 8 bulan pada tahun 2017. Data-data tersebut kemudian akan dianalisis polanya serta korelasinya dengan tata guna lahan di sekitarnya. Harapannya, kami dapat mengekstraksi tipe fluktuasi temperatur, TDS, dan kelembaban udara pada setiap lokasi tipe.

- Analisis multivariabel: Kami mengambil sampel sebanyak 10 titik pada berbagai lokasi di Bandung untuk digabungkan dengan 300 sampel air tanah dan air sungai yang kami miliki sejak tahun 2007. Variabel yang diukur dan dimasukkan ke dalam data mencakup variabel spasial (koordinat $\mathrm{x}, \mathrm{y}, \mathrm{z}$ ), unsur utama, unsur logam berat (besi dan mangan), silika, serta variabel terkait hujan. Rinciannya akan dijelaskan pada Bab 4.

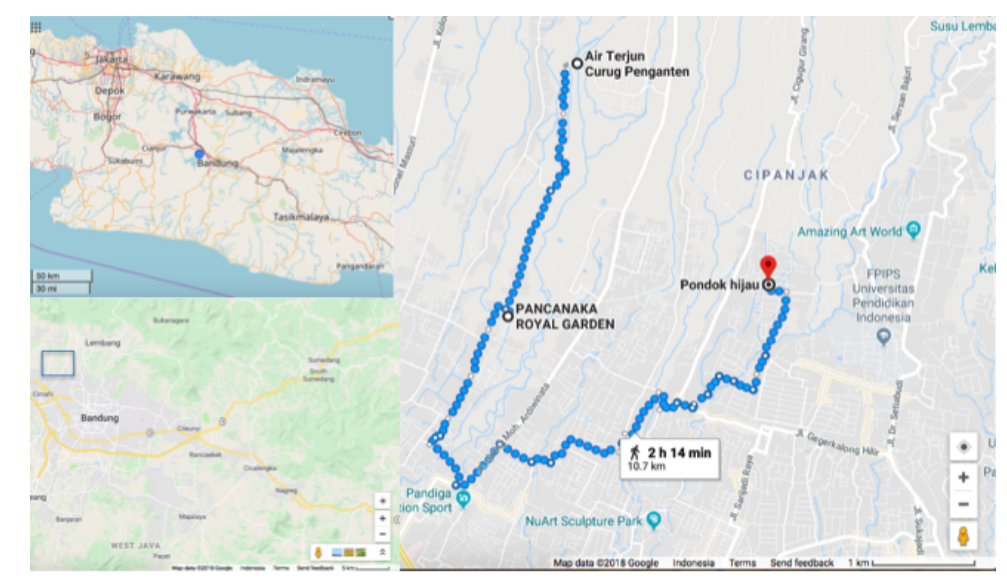

Gambar I.3 Tiga lokasi observasi

\section{I.0.4 Sistematika pembahasan}

Dalam kajian ini, sistematika pembahasan yang dilakukan adalah sebagai berikut:

Bab 1 Pendahuluan: Bab ini berisi tentang latar belakang yang mendasari dipilihnya penelitian ini, rumusan permasalahan, maksud dan tujuan yang ingin dicapai, kerangka pemikiran, serta sistematika pembahasan yang dilakukan untuk menyelesaikannya.

Bab 2 Tinjauan Pustaka: Berisi tentang uraian teori, aturan, standar ataupun pedoman yang berkaitan dengan permasalahan secara teoritis. 
Bab 3 Metode:Pada bab ini akan diuraikan metodologi

Bab 4 Tinjauan pustaka: Pada bab ini akan dipaparkan tinjauan pustaka dari sisi kondisi biogeofisik secara regional, serta sisi teoritis dari telaah kualitas air. Dalam bab ini akan juga dijelaskan mengenai pendekatan riset eksploratori yang digunakan dalam kegiatan ini.

Bab 5 Hasil dan pembahasan: Pada bab ini akan dibahas mengenai hasil pengukuran serta faktor-faktor yang mengendalikannya. Di sini pemikiran kami akan berbasis kepada data TDS, temperatur, dan fluktuasinya secara time series. Hasil tersebut kemudian dihubungkan dengan kondisi lapangan untuk ditentukan penyebabnya.

Bab 6 Kesimpulan dan rekomendasi: Pada bab ini berisi kesimpulan mengenai faktor-faktor yang menyebabkan terjadi fluktuasi TDS, saran alternatif penanganannya serta usulan riset berikutnya. 


\section{Bab II TINJAUAN PUSTAKA}

Tinjauan pustaka dilakukan dalam tiga topik, yaitu: interaksi antara air tanah dan air sungai (atau air permukaan), kualitas air, serta kontaminasi air. Bab ini disusun berdasarkan pencarian informasi melalui basis data Scopusdan Google Scholar.

\section{II.0.1 Telaah bibliometrik}

Metode bibliometrik ini bertujuan untuk membuat visualisasi lanskap riset di bidang kualitas air sungai dan air tanah. Dengan teknik ini, kami dapat menggambarkan situasi riset terkait dan bagaimana karakternya, mencakup: distribusi berdasarkan tahun, penulis, afiliasi, dan lembaga, serta keterkaitan antar artikel. Di sini kami memanfaatkan basis data Scopus dan Google Scholar, didukung perangkat open source VosViewer juga digunakan untuk membangun visualisasinya (Irawan dkk., 2018a).

Dari telaah secara terpisah dapat dilihat bahwa riset tentang interaksi antara air tanah dengan air permukaan/air sungai di dunia terdiri dari setidaknya 5 klaster riset berdasarkan temanya (Gambar II.1), yakni tema: kontaminasi, pemodelan, kualitas dan isotop, water balance, dan properti hidrolik ((Irawan dkk., 2018b)).

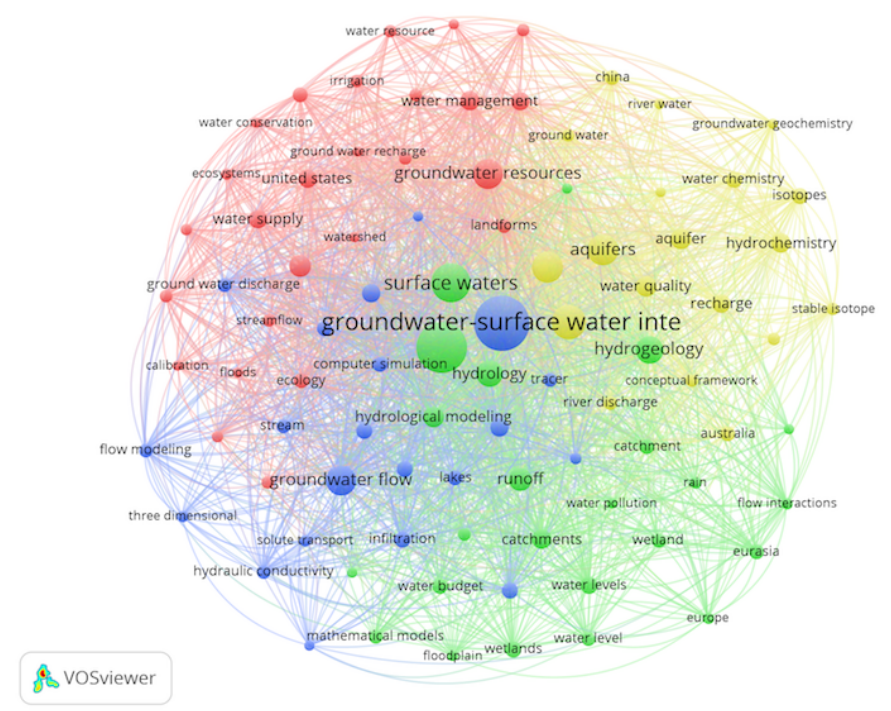

Gambar II.1 Jejaring kata kunci dalam lingkup riset bertema interaksi antara air tanah dan air permukaan/air sungai 
Yang menarik, dengan adanya interaksi yang erat antara bidang (direpresentasikan dengan jejaring kata kunci) pada Gambar II.1, ternyata tidak dibangun dari interaksi antar penulis yang erat. Jejaring penulis pada Gambar II.2 memperlihatkan ada segmentasi penulis berdasarkan geografi (negara) ((Irawan dkk., 2018b)).

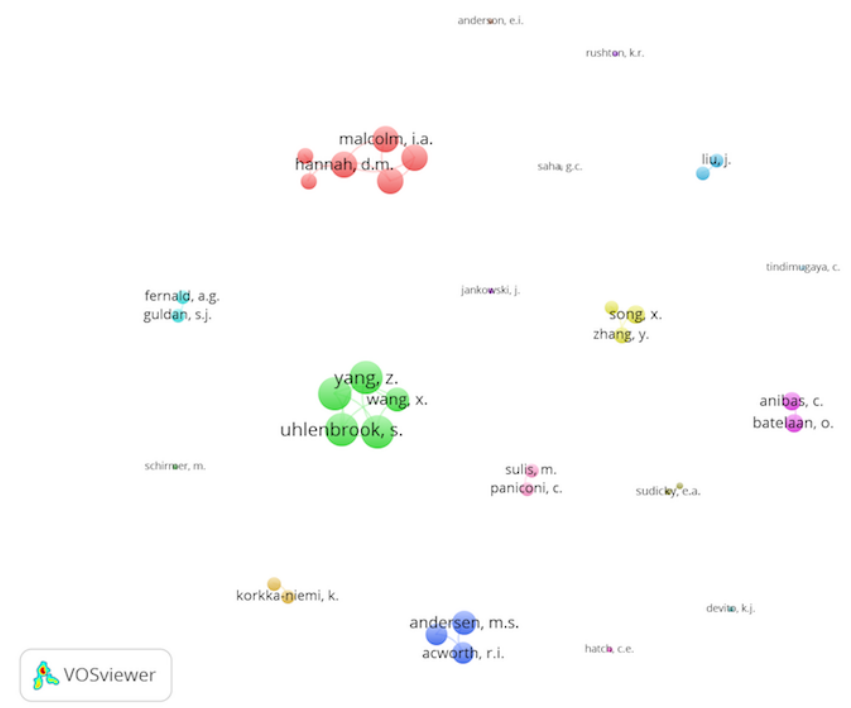

Gambar II.2 Jejaring penulis dalam lingkup riset bertema interaksi antara air tanah dan air permukaan/air sungai

Lebih jauh lagi bila kita bandingkan dengan riset hidrogeologi/hidrologi di Indonesia, dicerminkan dengan kata kunci Indonesia pada judul artikel, maka riset bertema interaksi antara air tanah dengan air permukaan/air sungai masih sangat jarang. Hasil pencarian di database Scopus menghasilkan dokumen kurang dari 100. Tema ini dapat dikembangkan lebih lanjut. 


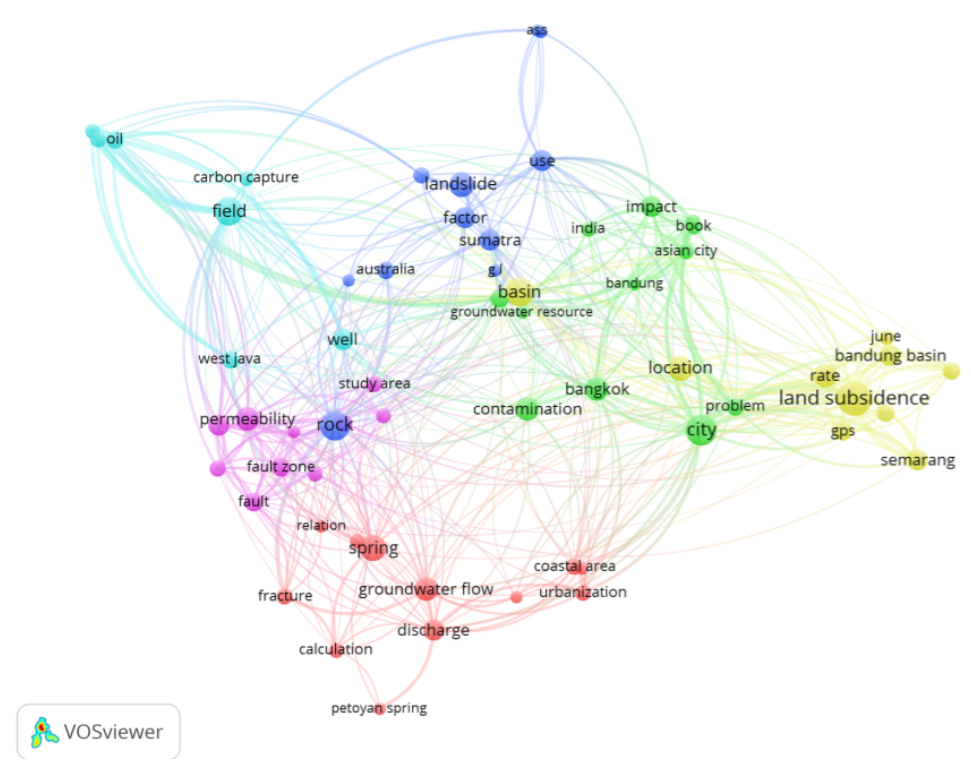

Gambar II.3 Jejaring kata kunci artikel bertema hidrologi/hidrogeologi Indonesia
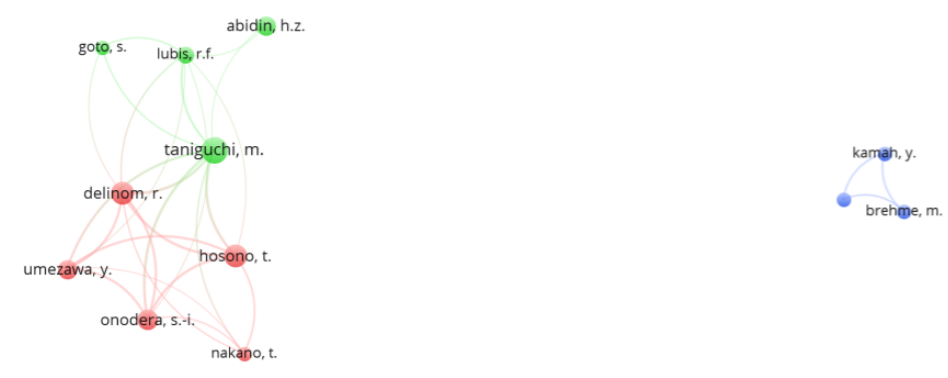

fis Vosviewer

Gambar II.4 Jejaring penulis dalam lingkup riset bertema hidrologi/hidrogeologi Indonesia

\section{II.0.2 Total dissolved solids/Zat padat terlarut}

Air adalah pelarut yang baik. Zat padat terlarut atau total dissolved solids (TDS) adalah akibatnya. Padatan yang dimaksud di sini adalah mineral, garam, logam, kation atau anion yang terlarut dalam air. Semakin banyak yang terlarut, maka semakin tinggi nilai TDS nya, biasanya diukur dalam satuan parts per million (ppm). TDS dapat berasal dari air secara alamiah atau dari zat pencemar (kontaminan). Dalam kasus air sungai, biasanya semakin ke arah hilir, nilai TDS akan makin tinggi ins_cite. Secara alamiah TDS akan berasal dari mineralmineral yang berasal dari bebatuan atau tanah yang ada di sepanjang bantaran 
sungai. Di sisi lain, TDS akan meningkat bila dalam perjalanannya, air sungai menerima kontaminan akan berasal dari saluran-saluran limbah rumah tangga atau industri yang bermuara ke sungai.

Kualitas air sungai sangat sensitif terhadap perubahan tata guna lahan. Salah satu indikatornya adalah BOD, yang akan cepat berubah bila ada pencemaran yang berkaitan dengan bahan organik, seperti perkebunan Sawit (Priyambada dkk., 2008). Hal yang sama terjadi untuk parameter TSS dan TDS (Liu dkk., 2017; Putra dan Putra, 2014).

Berkaitan dengan TDS, kami berpendapat bahwa peningkatan nilai TDS, yang tidak wajar dan terindikasi dari sumber-sumber buatan/aktivitas manusia, dapat menjadi indikasi penurunan kualitas lingkungan (Gambar II.5). Peningkatan TDS yang tidak wajar dapat berasal dari aktivitas manusia, misalnya pembuangan limbah cair rumah tangga (limbah domestik) atau Tempat Pembuangan Sampah Sementara (TPS) yang kadang berada di tepi sungai. Air lindinya dapat meresap ke dalam tanah dan pada akhirnya akan mencemari air sungai dan air tanah di sekitarnya. Model usulan kami untuk menjelaskan peningkatan TDS dapat dilihat pada Gambar II.6.

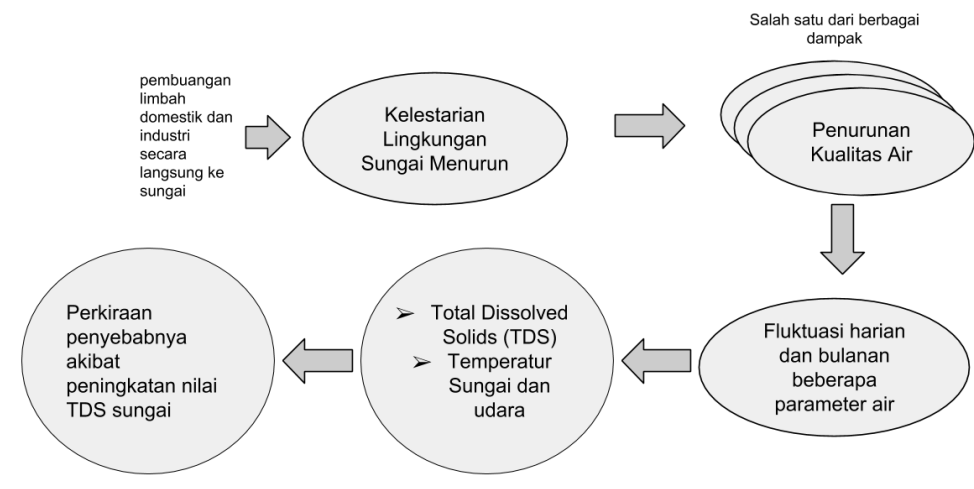

Gambar II.5 Model peningkatan TDS sebagai salah satu indikator penurunan kualitas lingkungan hidup

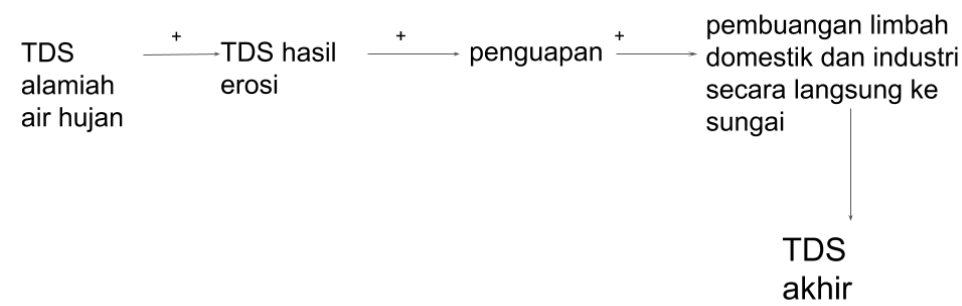

Gambar II.6 Model alur peningkatan TDS dari hulu ke hilir 


\section{II.0.3 Suhu air dan suhu udara}

Suhu air sungai akan sangat berhubungan dengan suhu udara. Hal yang berlainan dapat terjadi untuk kasus air tanah. Suhu air tanah dalam atau sangat dalam yang mengalir dalam akuifer tertekan dapat saja tidak berhubungan dengan suhu udara. Dalam riset ini hipotesis kami adalah bila suhu air sungai memiliki tren yang mengikuti suhu udara, maka dapat diinterpretasikan bahwa air tanah yang mengalir ke sungai berasal dari akuifer tak tertekan.

\section{II.0.4 Terkait analisis}

Seperti telah disampaikan sebelumnya, analisis yang dilakukan dalam riset ini mencakup analisis time series dan analisis multivariabel (Gambar II.7). Keduanya digunakan untuk mengetahui proses yang terjadi pada air tanah dan air sungai di Bandung.

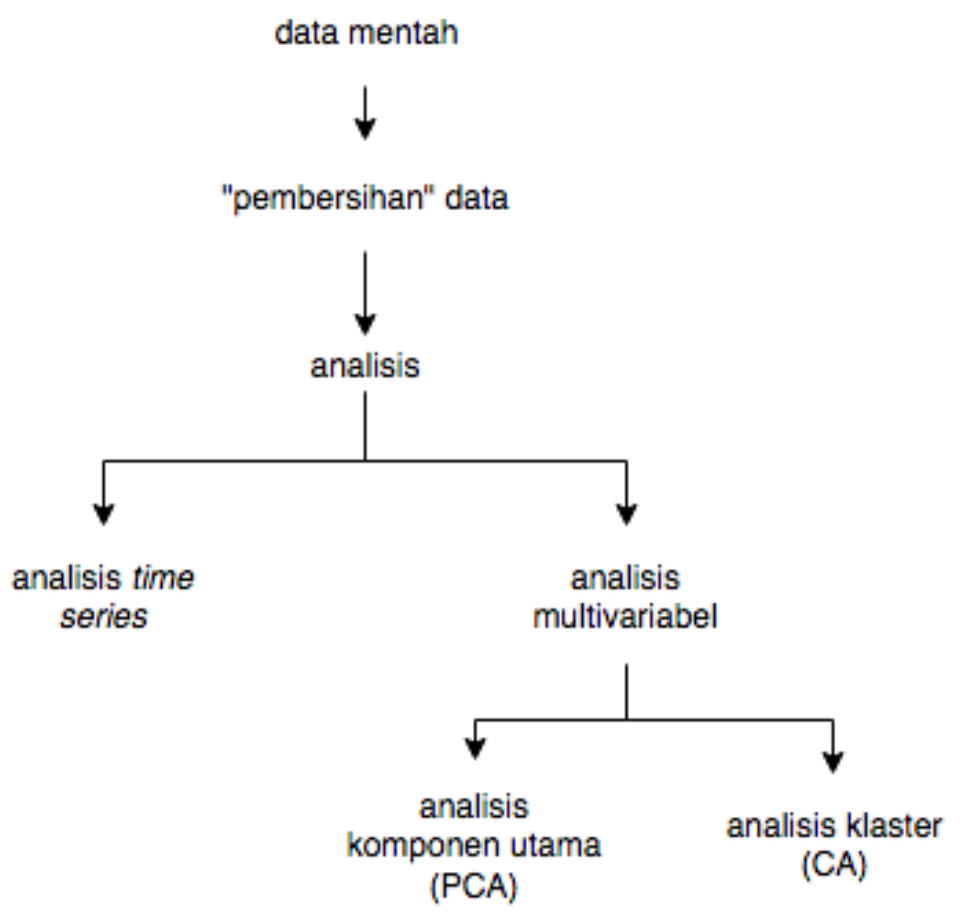

Gambar II.7 Struktur analisis dalam riset

\section{Analisis time series}

Analisis data time series bertujuan untuk mengetahui pola data terhadap waktu, sekaligus memprediksi data di masa depan (Gio, 2018; Bo, 2013). Dalam riset ini, kami fokus tujuan pertama, mengetahui pola data terhadap waktu. Hasilnya sebagai dasar bagi kami untuk mengidentifikasi proses yang terjadi dan membuat 
interpretasi lebih baik Gambar II.8.

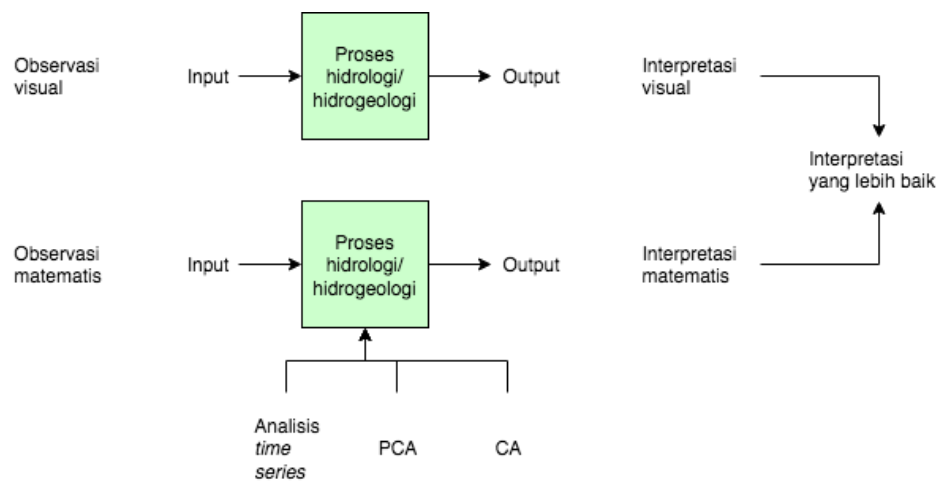

Gambar II.8 Analisis time series, PCA dan CA untuk memperbaiki interpretasi visual

\section{Analisis multivariabel}

Analisis multivariabel PCA bertujuan untuk mencari variabel (yang jumlahnya banyak) yang secara dominan mengendalikan data. Dalam PCA, variabel ditransformasikan menjadi set variabel baru bernama komponen. Kemudian masingmasing data (sampel kualitas air) diproyeksikan kepada sumbu x dan y yang merepresentasikan komponen 1 (PC1) dan komponen 2 (PC2) hasil transformasi PCA tersebut. Untuk Analisis Klaster (CA), mirip dengan PCA, data kualitas air dihitung jaraknya (eucledian distance) secara relatif satu sama lain (Irawan, 2017; Ramdani dkk., 2017). Kami menggunakan keduanya untuk mengetahui pengelompokkan variabel dominan dan sampel data. 


\section{Bab III METODE PENELITIAN}

\section{III.0.1 Jenis riset}

Riset ini berjenis eksploratori (Raaijmakers dkk., 2008) yang bertujuan untuk mengetahui berbagai korelasi dan hubungan sebab akibat yang mungkin terjadi pada data atau variabel yang diukur di lapangan ((Commons, 2014)). Fokus utama dari riset ini adalah pengukuran variasi data kualitas air yang terdiri dari debit sungai, temperatur air sungai dan temperatur udara, zat padatan terlarut (TDS), dan $\mathrm{pH}$. Variasi data ini secara rinci masih sangat jarang ditelaah. Dalam analisisnya nanti, penulis akan banyak menggunakan fungsi-fungsi penelaahan data kohort dengan piranti lunak R (R Core Team, 2014) dan package forecast serta fungsi pemodelan multiregresi (Texas A \& M University, 2017; ColumbiaUniversity, 2017; HarvardUniversity, 2017).

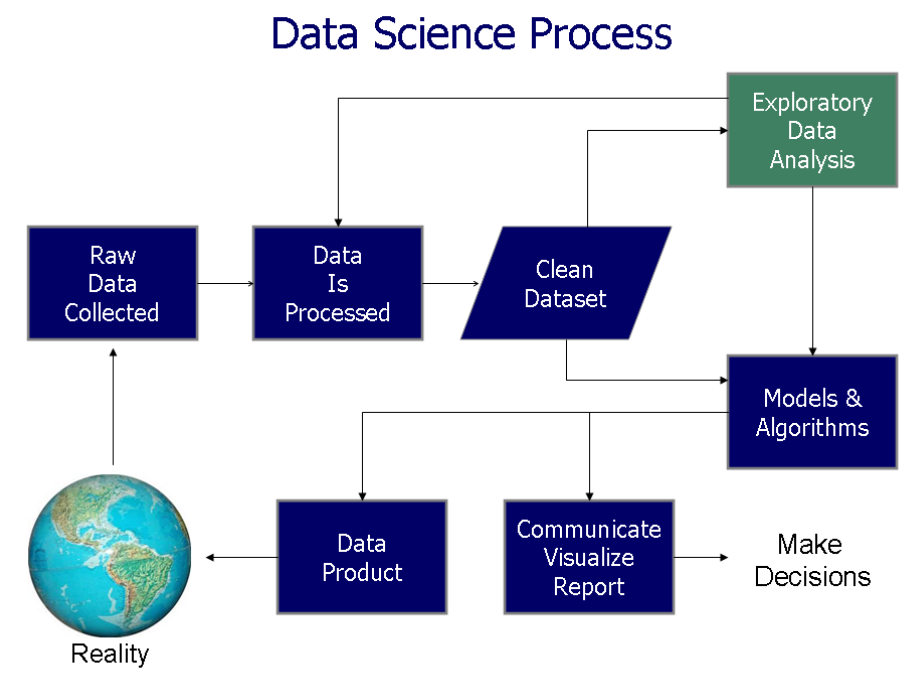

Gambar III.1 Alur pikir riset eksploratori berdasarkan prinsip data science

\section{III.0.2 Pengelolaan data riset}

Data dari riset ini terdiri dari tabel, foto dan video, sedangkan analisis berbentuk kode, tabel, dan grafik. Secara keseluruhan data dan analisis tersebut kami simpan dalam repositori proyek Open Science Framework (OSF) (Irawan dan Aditya, 2018) sebagai proyek data terbuka (open data project). Seluruh komponen riset akan dipublikasikan dengan lisensi CC-BY (Creative Commons Attribution 4.0 International CC BY 4.0, n.d.) saat tesis ini telah lolos proses sidang magister. 
Dokumentasi proyek riset terbagi ke dalam beberapa komponen, mengikuti panduan dari Project TIER ((TIER, 2014) pada Gambar III.4):

1. Komponen teks dan slide presentasi disimpan dalam Google Drive dan Overleaf. Kami menggunakan Overleaf sebagai platform penulisan tesis menggunakan LATEX.

2. Komponen kode $\mathrm{R}$ dan data terolah disimpan sebagai repositori GitHub.

3. Komponen data mentah orisinal disimpan dalam repositori Open Science Framework (OSF).

4. Ketiga komponen di atas diintegrasikan dalam repositori proyek OSF.

5. Seluruh komponen akan dibuka aksesnya untuk publik segera setelah tesis lolos ujian sidang.

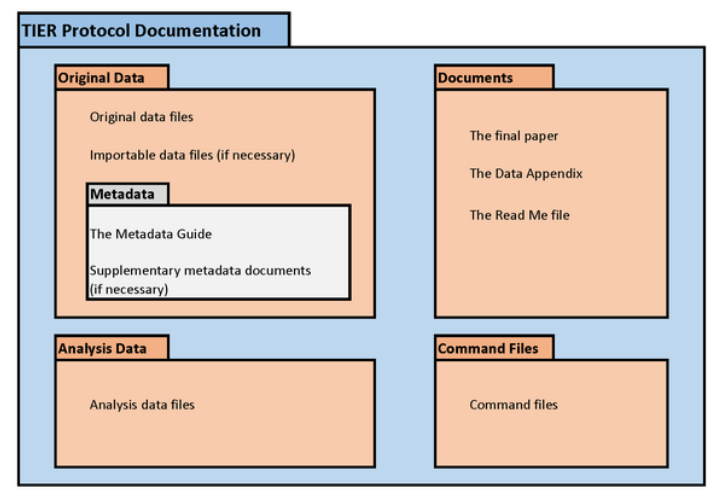

Gambar III.2 Struktur folder dan data riset dalam spesifikasi Project TIER 


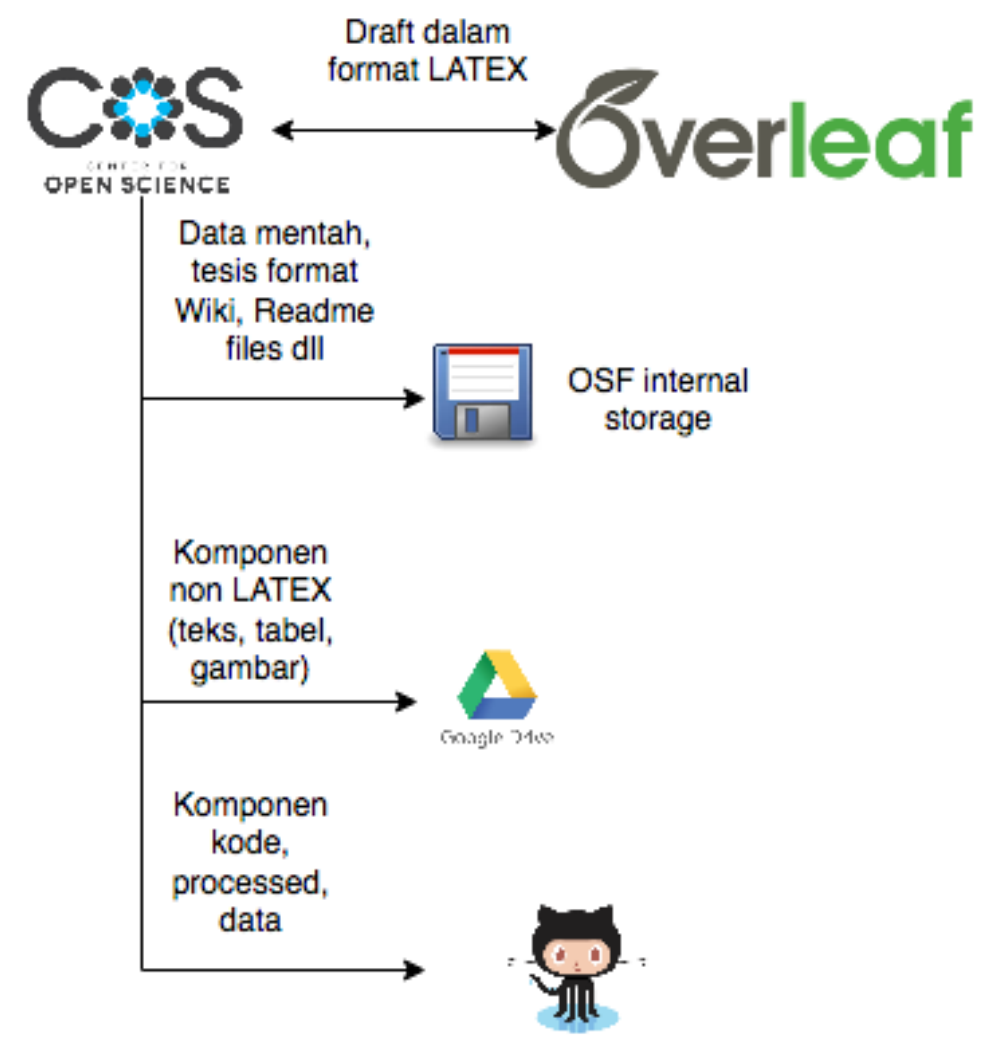

Gambar III.3 Struktur repositori dan penyimpanan berkas riset

\section{III.0.3 Uraian data}

Data yang didapatkan dari riset ini merupakan bagian dari observasi data kualitas air Sungai Cikapundung pada periode Maret-November 2017. Berikut ini adalah beberapa parameter yang diukur di lapangan Tabel IV.1.

Tabel III.1 Variabel yang diukur di lapangan

\begin{tabular}{|ccc|}
\hline Variables & Units (satuan) & Singkatan \\
\hline Debit & meter kubik/detik & $\mathrm{m}^{3} / \mathrm{det}$ \\
Temperatur air sungai & derajat Celsius & ${ }^{\circ} \mathrm{C}$ \\
Temperatur udara & derajat Celsius & ${ }^{\circ} \mathrm{C}$ \\
Zat padatan terlarut & parts per million & $\mathrm{ppm}$ \\
\hline
\end{tabular}

Pengukuran dilakukan dengan alat portabel merk Lutron, masing-masing dengan ketelitian 0.01 pada masing-masing satuan yang berkaitan. Pengukuran dilakukan empat kali di masing-masing lokasi: pukul 10.00, 12.00, 14.00, dan 16.00. Pengukuran dilakukan pada tiga lokasi di DAS S. Cikapundung (diurutkan dari utara-selatan):

1. S. Ciawitali lokasi Curug Panganten (L1), 
2. S. Ciawitali lokasi Grand Royal Pancanaka (L2),

3. S. Cibeureum lokasi Pondok Hijau Indah (L3).

Tata guna lahan berevolusi dari lahan terbuka berupa hutan dan lahan perkebunan/pertanian di lokasi CP dan GRP, menjadi perumahan di PHI.

\section{III.0.4 Analisis time series}

Analisis data time series menggunakan $R$ dan package forecast. Fungsi utama yang digunakan adalah sebagai berikut.

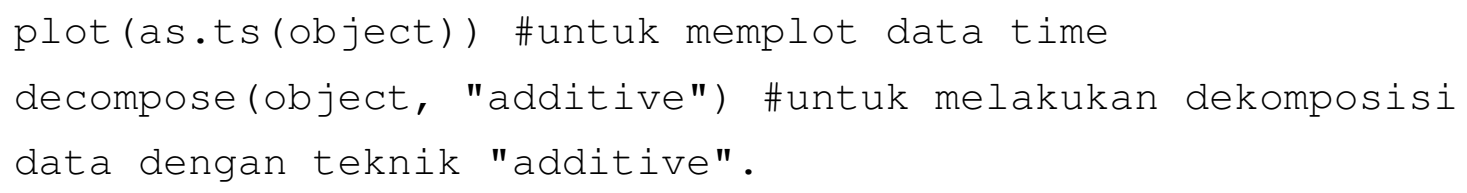

Outputnya adalah untuk mengurai komponen data time series seperti ilustrasi di bawah ini ((io, 2015)).

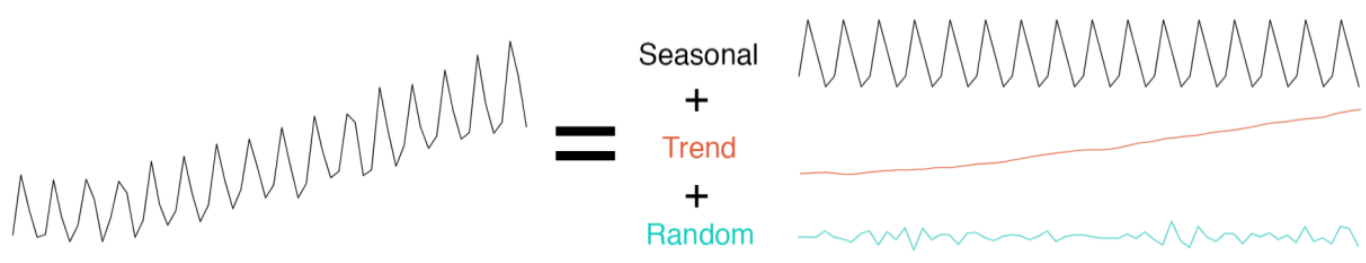

Decomposition (Anomaly.io)

Gambar III.4 Ilustrasi proses dekomposisi data time series

\section{III.0.5 Analisis multivariabel}

Prosedur yang dilakukan untuk analisis komponen prinsipal (PCA):

- load data menggunakan fungsi read. csv $<-$ (file)

- pemisahan kolom bertipe data numerik menjadi dataframe terpisah

- penghitungan PCA menggunakan fungsi res.pca $<-p c a($ dataframe). res. pca adalah dataframe baru berisi hasil perhitungan PCA. Proses normalisasi juga telah dilakukan dalam tahap ini secara otomatis

- visualisasi grafik loading atau pengaruh variabel kepada komponen dan score atau posisi relatif sampel terhadap komponen dengan fungsi fviz $z_{p} c a_{i} n d\left(\right.$ res.pca) dan $f v i z_{p} c a_{v}$ ar (res.pca).

Prosedur yang dilakukan untuk analisis klaster (CA):

- load data menggunakan fungsi read.csv $<-$ (file) 
- pemisahan kolom bertipe data numerik menjadi dataframe terpisah

- penghitungan CA menggunakan fungsi cluster $<-$ fviz $_{n} b c l u s t$ (dataframe). cluster adalah dataframe baru berisi hasil perhitungan CA. Proses normalisasi juga telah dilakukan dalam tahap ini secara otomatis

- visualisasi grafik dengan fungsi fvizcluster(cluster)

Kode R untuk PCA dan CA dapat dilihat pada Lampiran 1. Kode nantinya akan tersedia di repositori GitHub kami. 


\section{Bab IV DATA}

\section{IV.0.1 Jenis riset}

Riset ini berjenis eksploratori (Raaijmakers dkk., 2008) yang bertujuan untuk mengetahui berbagai korelasi dan hubungan sebab akibat yang mungkin terjadi pada data atau variabel yang diukur di lapangan. Fokus utama dari riset ini adalah pengukuran variasi data kualitas air yang terdiri dari debit sungai, temperatur air sungai dan temperatur udara, zat padatan terlarut (TDS), dan $\mathrm{pH}$. Variasi data ini secara rinci masih sangat jarang ditelaah. Dalam analisisnya nanti, penulis akan banyak menggunakan fungsi-fungsi penelaahan data kohort dengan piranti lunak $\mathrm{R}$ (R Core Team, 2014) dan package forecast (?) serta fungsi pemodelan multiregresi (Texas A \& M University, 2017; ColumbiaUniversity, 2017; HarvardUniversity, 2017).

\section{IV.0.2 Pengelolaan data}

Data dari riset ini terdiri dari tabel, foto dan video, sedangkan analisis berbentuk kode, tabel, dan grafik. Secara keseluruhan data dan analisis tersebut kami simpan dalam repositori proyek Open Science Framework (OSF) (Irawan dan Aditya, 2018) sebagai proyek data terbuka (open data project). Seluruh komponen riset akan dipublikasikan dengan lisensi CC-BY (Creative Commons Attribution 4.0 International CC BY 4.0, n.d.) saat tesis ini telah lolos proses sidang magister.

\section{IV.0.3 Uraian data}

\section{Data time series}

Data yang didapatkan dari riset ini merupakan bagian dari observasi data kualitas air Sungai Cikapundung di tahun 2017. Makalah ini menjelaskan hasil sementara dari riset yang masih berjalan untuk mengetahui variasi harian yang mungkin terjadi pada parameter sebagai berikut Tabel IV.1.

Tabel IV.1 Variabel yang diukur di lapangan

\begin{tabular}{|ccc|}
\hline Variables & Units (satuan) & Singkatan \\
\hline Debit & meter kubik/detik & $\mathrm{m}^{3} / \mathrm{det}$ \\
Temperatur air sungai & derajat Celsius & ${ }^{\circ} \mathrm{C}$ \\
Temperatur udara & derajat Celsius & ${ }^{\circ} \mathrm{C}$ \\
Zat padatan terlarut & parts per million & $\mathrm{ppm}$ \\
\hline
\end{tabular}

Pengukuran dilakukan dengan alat portabel merk Lutron, masing-masing dengan 
ketelitian 0.01 pada masing-masing satuan yang berkaitan. Pengukuran dilakukan empat kali di masing-masing lokasi: pukul 10.00, 12.00, 14.00, dan 16.00. Pengukuran dilakukan pada tiga lokasi di DAS S. Cikapundung (diurutkan dari utara-selatan):

1. S. Ciawitali lokasi Curug Panganten (CP),

2. S. Ciawitali lokasi Grand Royal Pancanaka (GRP),

3. S. Cibeureum lokasi Pondok Hijau Indah (PHI).

Tata guna lahan berevolusi dari lahan terbuka berupa hutan dan lahan perkebunan/pertanian di lokasi CP dan GRP, menjadi perumahan di PHI (akan dijelaskan pada Bab 5).

\section{Data kualitas air}

Data kualitas air terdiri dari dua bagian dengan sumber berbeda: bagian pertama adalah 300 baris data kualitas air yang merupakan kumpulan data dari riset Tim Cikapundung KK Geologi Terapan, FITB, ITB (data sitasi akan disisipkan kemudian), dan bagian kedua adalah 10 baris data kualitas air yang diambil dalam lingkup riset ini. Data selengkapnya dapat dilihat pada lampiran 2 dan nantinya akan tersedia di repositori data riset kami. 


\section{Bab V HASIL DAN PEMBAHASAN}

\section{V.0.1 Temperatur udara dan temperatur air sungai}

Temperatur udara dan temperatur air sungai memperlihatkan siklus yang konsisten di tiga lokasi observasi. Temperatur udara lebih tinggi kurang lebih $10-20{ }^{\circ} \mathrm{C}$. Pola kedua temperatur tersebut dapat dilihat pada gambar di bawah ini (Gambar V.1).

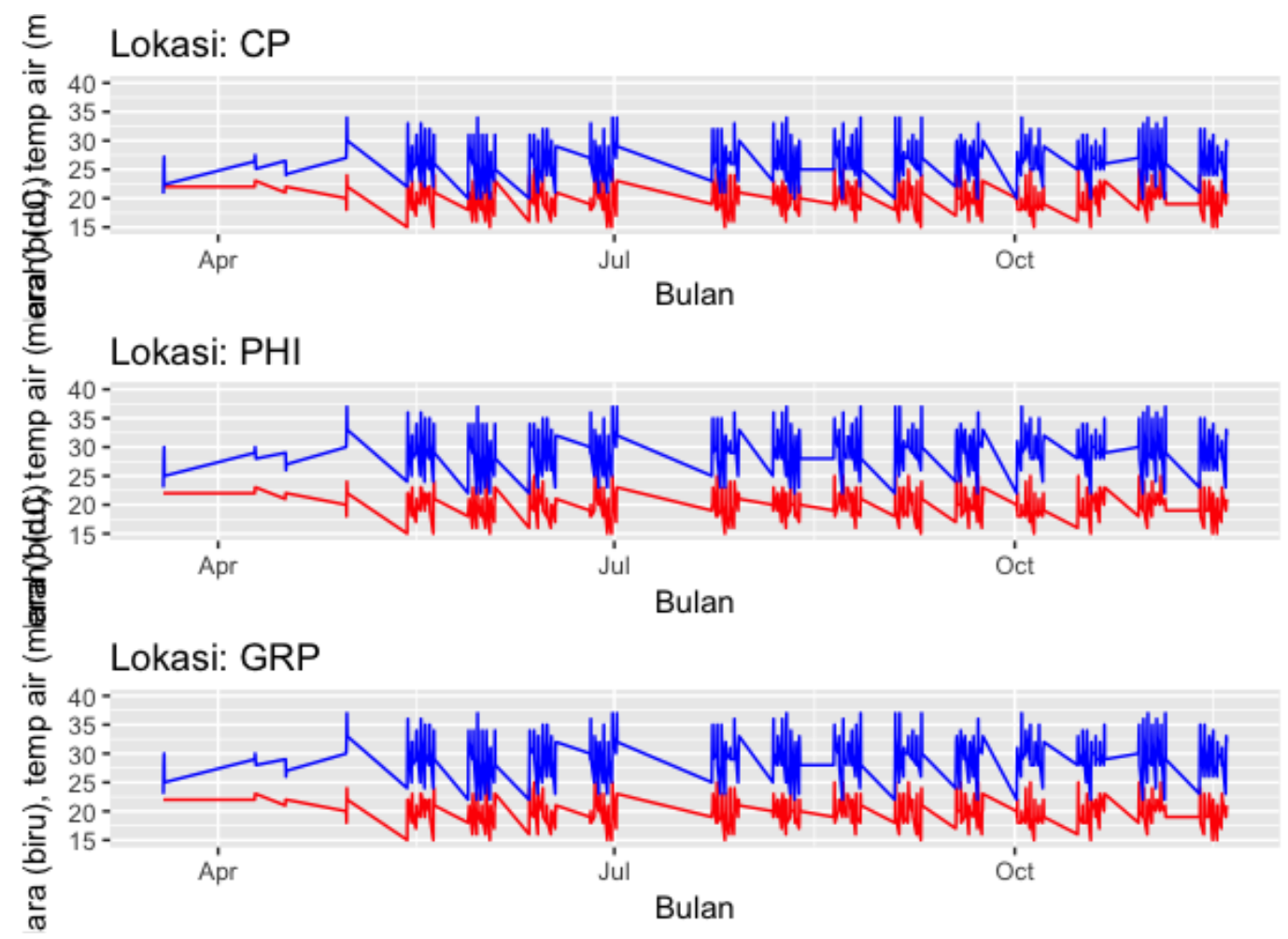

Gambar V.1 Plot temperatur udara (biru) dan temperatur sungai (merah) di lokasi CP.

Dari gambar tersebut dapat dilihat bahwa temperatur udara berkisar antara 20 hingga $34^{\circ} \mathrm{C}$, sedangkan temperatur sungai berkisar antara 15 hingga $25^{\circ} \mathrm{C}$. Pola yang konsisten ini disebabkan karena air sungai memiliki kontak yang terusmenerus dengan temperatur udara. Rendahnya temperatur air sungai dibanding temperatur udara juga dapat disebabkan karena air sungai sebagian besar berasal dari air tanah yang masuk ke sungai, atau disebut sebagai sistem efluen (Irawan dan Aditya, 2018; Darul dkk., 2016). Menurut beberapa rujukan tersebut, akuifer tidak tertekan menyuplai air tanah ke sungai di kawasan Cekungan Bandung. Temperatur udara masih memiliki hubungan yang erat dengan temperatur air tanah di dalam akuifer tak tertekan. 


\section{V.0.2 TDS}

Nilai TDS di lokasi CP memperlihatkan kisaran antara 60-70 ppm (Gambar V.3 atas), sedangkan di lokasi GRP dan PHI, yang elevasinya lebih rendah, memperlihatkan kisaran yang lebih tinggi, yakni antara 80 hingga 150 ppm (Gambar V.3 tengah untuk PHI dan bawah untuk GRP). Dua kisaran nilai TDS tersebut masih tergolong air tawar (fresh water), masih kurang dari 500 ppm (Hayashi, 2004; Ramakrishnaiah dkk., 2009). Penggolongan air berikut ini menggolongkan air dengan TDS hingga 200 ppm adalah layak minum (Premier Water Minnesota). Menurut klasifikasi tersebut, maka air sungai di bagian yang lebih hilir, kawasan muara S. Cikapundung ke S. Citarum, tidak layak untuk diminum, kecuali diproses secara kimiawi. Di luar masalah kelayakan minum, bagi kami fluktuasinya yang menarik.

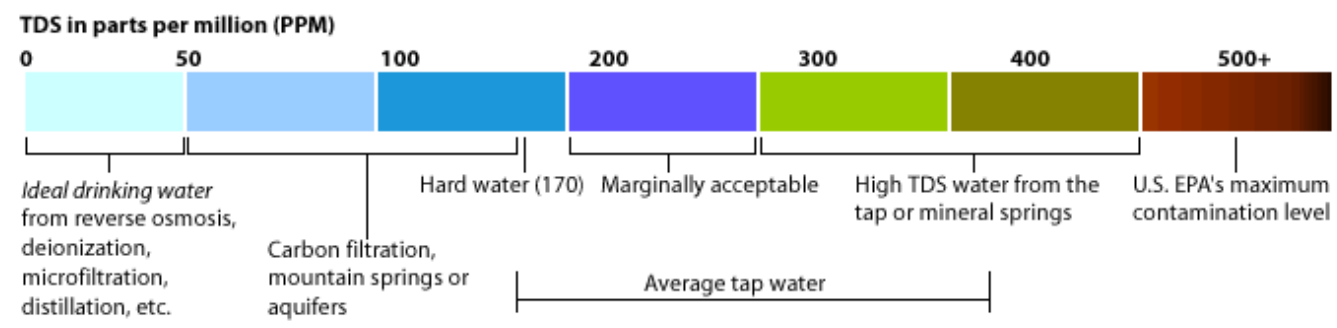

Gambar V.2 Klasifikasi air berdasarkan nilai TDS (Premier Water Minnesota)

Kemudian plot time series untuk dapat TDS dapat dilihat pada tiga gambar di bawah ini (Gambar V.4 dan Gambar V.5). Dari ketiga gambar tersebut didapatkan siklus mingguan secara konsisten. Nilai rendah pada Hari Selasa hingga Kamis, kemudian meningkat sejak Hari Jumat hingga Senin. Kemudian nilai menjadi normal kembali di Hari Selasa hingga Kamis. Menurut kami, pola ini dapat terjadi sebagai akibat dari aktivitas manusia yang meningkat pada hari libur (weekend) dan menurun di hari kerja (weekday). Bisa jadi, aktivitas ini berkaitan dengan dengan aktivitas wisatawan di kala libur. Di sekitar kawasan observasi memang terdapat banyak lokasi wisata juga akomodasi (hotel dalam berbagai ukuran dan jumlah kamar).

Selain karena lokasinya yang lebih rendah (lebih ke hilir), perbedaan nilai TDS yang signifikan tersebut (kurang lebih mencapai dua kali lipat) juga disebabkan oleh pengaruh aktivitas manusia. Tren peningkatan nilai TDS hingga mendekati 300 ppm di bagian hilir S. Cikapundung juga muncul di berbagai laporan riset (Irawan dan Furqon, 2017; Salim dan Dharmawan, 2017). Kondisi yang sama juga terlihat 


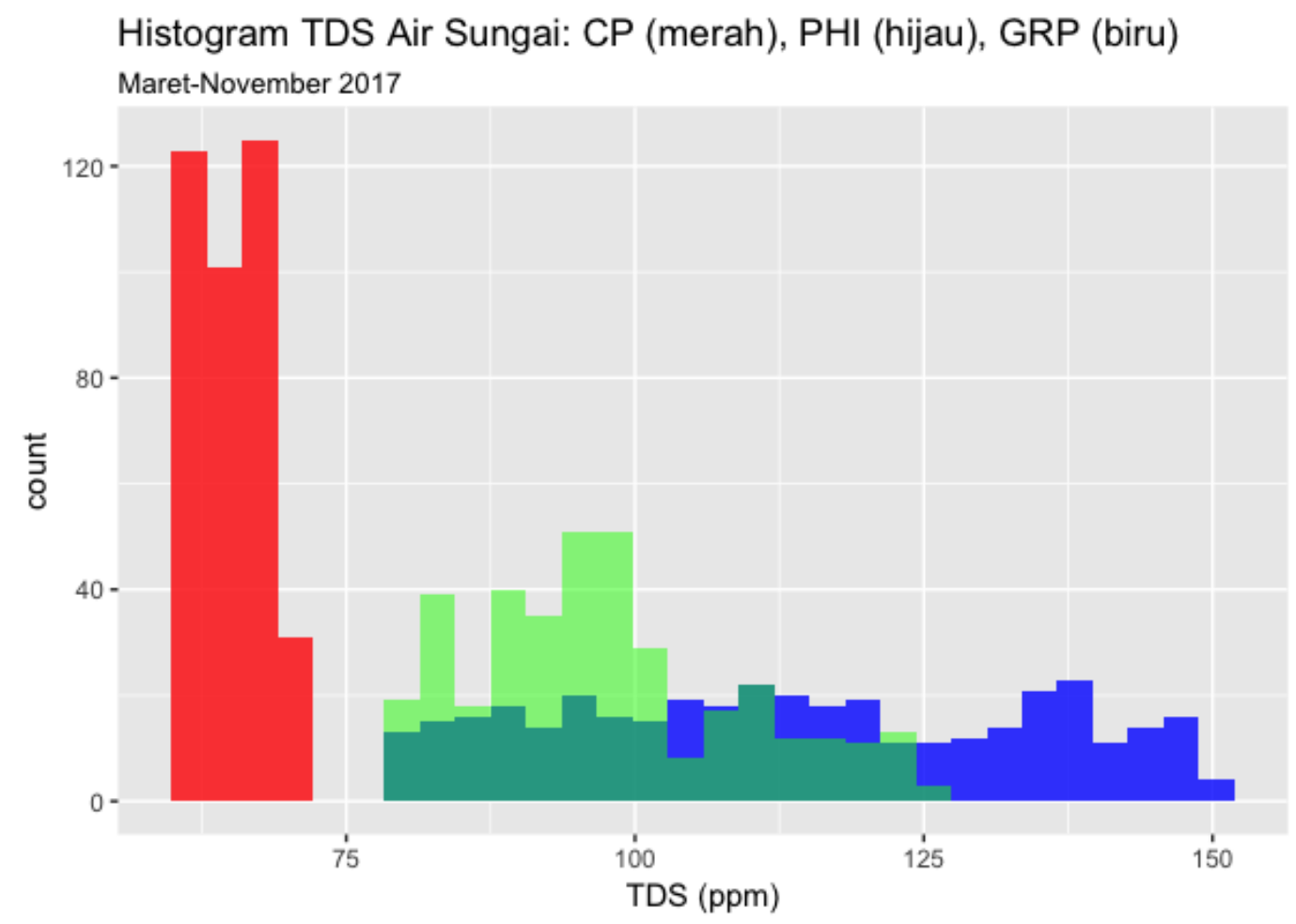

Gambar V.3 Plot histogram TDS di lokasi CP (atas), PHI (tengah), dan GRP (bawah).

di S. Cisadane (Irawan dkk., 2016). Menurut riset sebelumnya, TDS yang tinggi di S. Cisadane juga diduga berasal dari industri pelapisan logam skala rumah tangga yang ada di tepian sungai.

Hasil dekomposisi data time series TDS disampaikan pada Gambar V.6, Gambar V.8, dan Gambar V.7. Dengan dekomposisi, kami dapat mengetahui apakah ada pola yang berulang (siklis) dari data yang ada. Teknik ini, menggunakan bantuan R package forecast (Hyndman dan Khandakar, 2008; Hyndman, 2017) melihat pola grafik residual (noise), grafik paling bawah di tiap dekomposisi, kami melihat bahwa siklus mingguan di lokasi CP dan PHI lebih kuat dibanding lokasi GRP. Kondisi ini mungkin disebabkan karena CP dan PHI berada di kawasan dengan aktivitas manusia yang berpola konsisten. Untuk lokasi GRP, siklus tidak terlalu terlihat, mungkin karena aktivitas manusia di kawasan itu relatif sama.

Di Lokasi CP, kami mengidentifikasi kompleks pemukiman dan wisata Villa Katumiri. Lokasi ini, selain memiliki pemukiman konvensional juga memiliki kawasan wisata perkemahan dan outbound. Kedua kegiatan ini sangat aktif di kala libur. Pemukimannya sendiri banyak yang berkembang menjadi rumah sewa. 
Plot TDS (ppm) Maret - November 2017 di lokasi CP

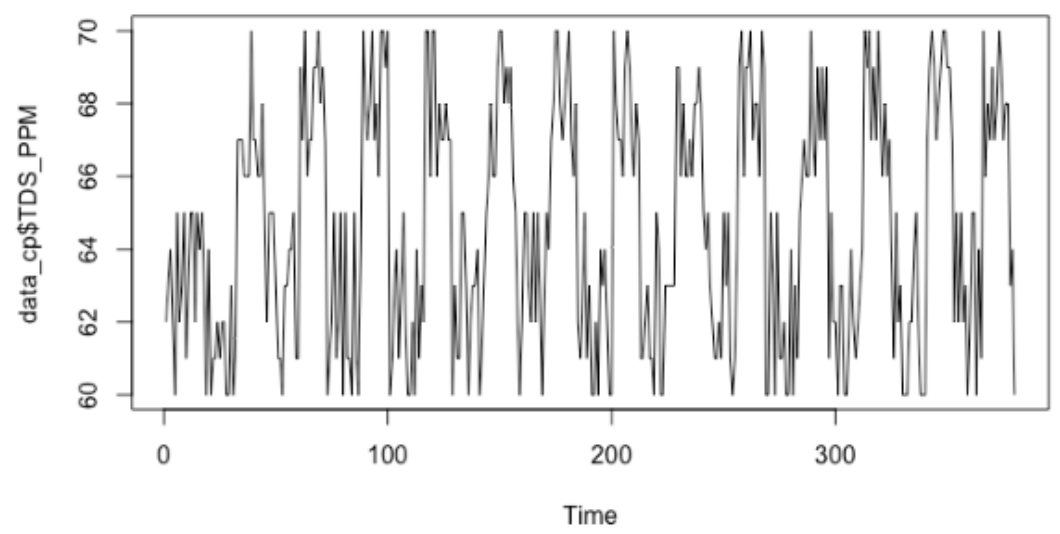

Plot TDS (ppm) Maret - November 2017 di lokasi PHI

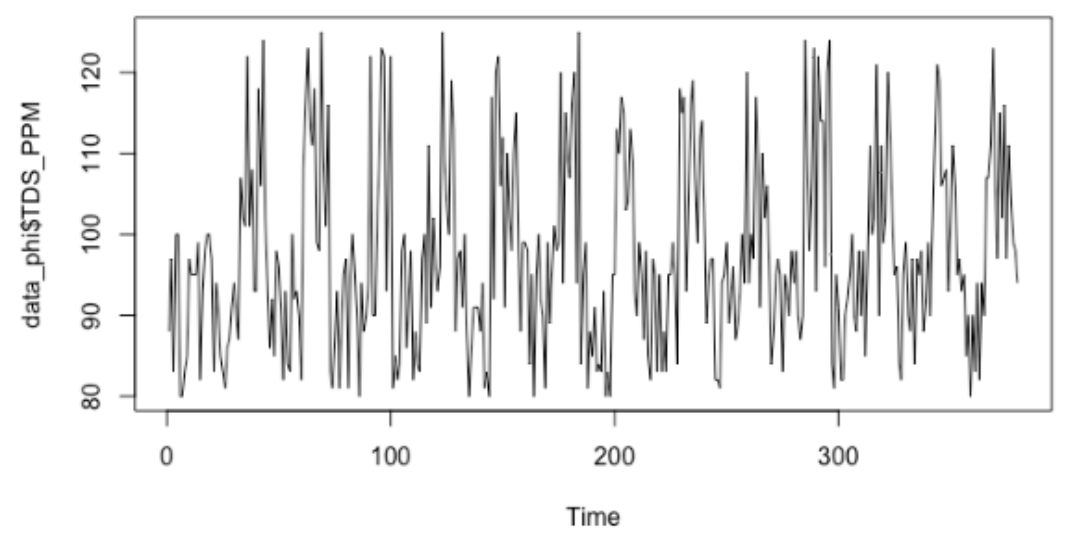

Plot TDS (ppm) Maret - November 2017 di lokasi GRP

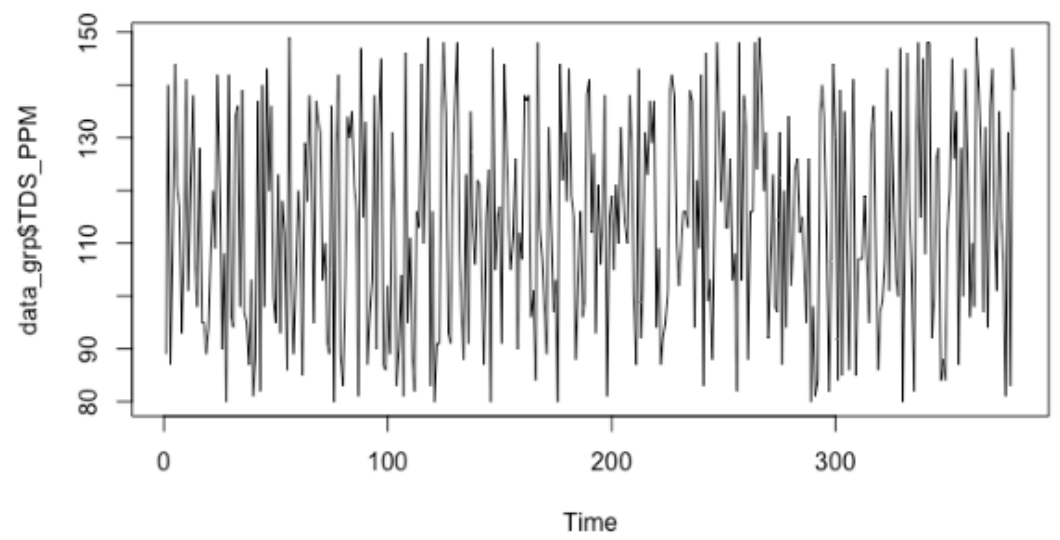

Gambar V.4 Plot time series TDS di lokasi CP (atas), PHI (tengah), dan GRP (bawah).

Dua lokasi lainnya, GRP dan PHI, adalah lokasi pemukiman dengan sistem drainase yang mengalir menuju ke sungai di dekatnya (lokasi observasi). Di lokasi GRP, 


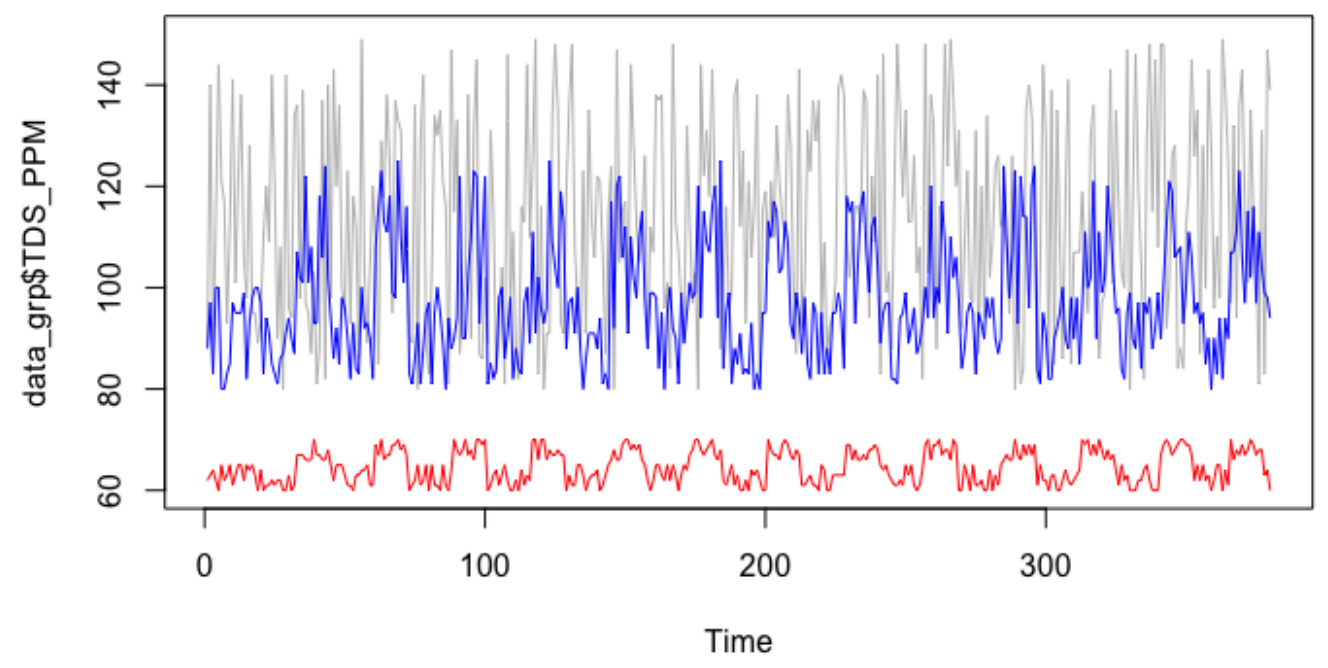

Gambar V.5 Plot time series TDS dalam satu plot untuk memudahkan melihat kisaran angka (abu: GRP, biru: PHI, dan merah CP)

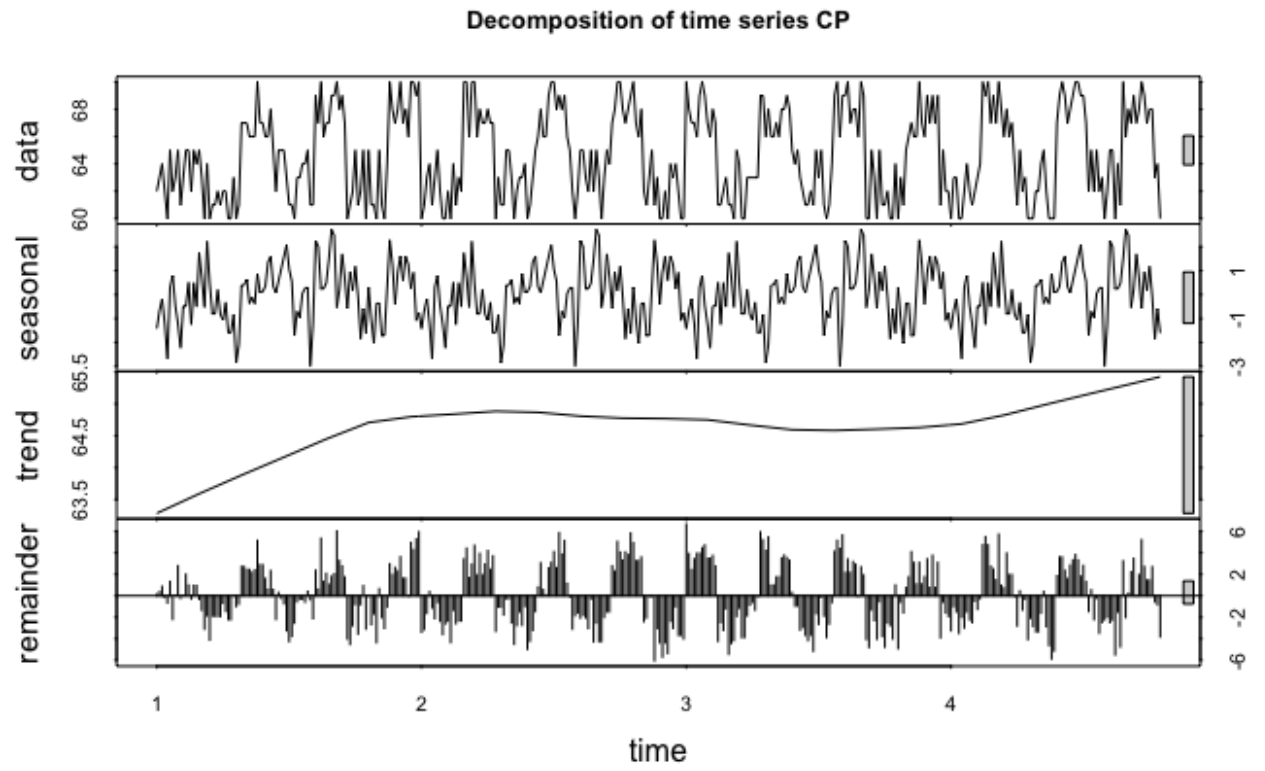

Gambar V.6 Analisis dekomposisi data TDS di lokasi CP

pengelola membuat sodetan melewati pemukiman tersebut. Jadi saluran sungai alami terhubung dengan sistem drainase pemukiman. Beberapa petak lahan sawah juga terlihat di lokasi, yang juga berpotensi menambah nilai TDS di air sungai. Beberapa foto dan video yang memperlihatkan saluran pembuangan dari 


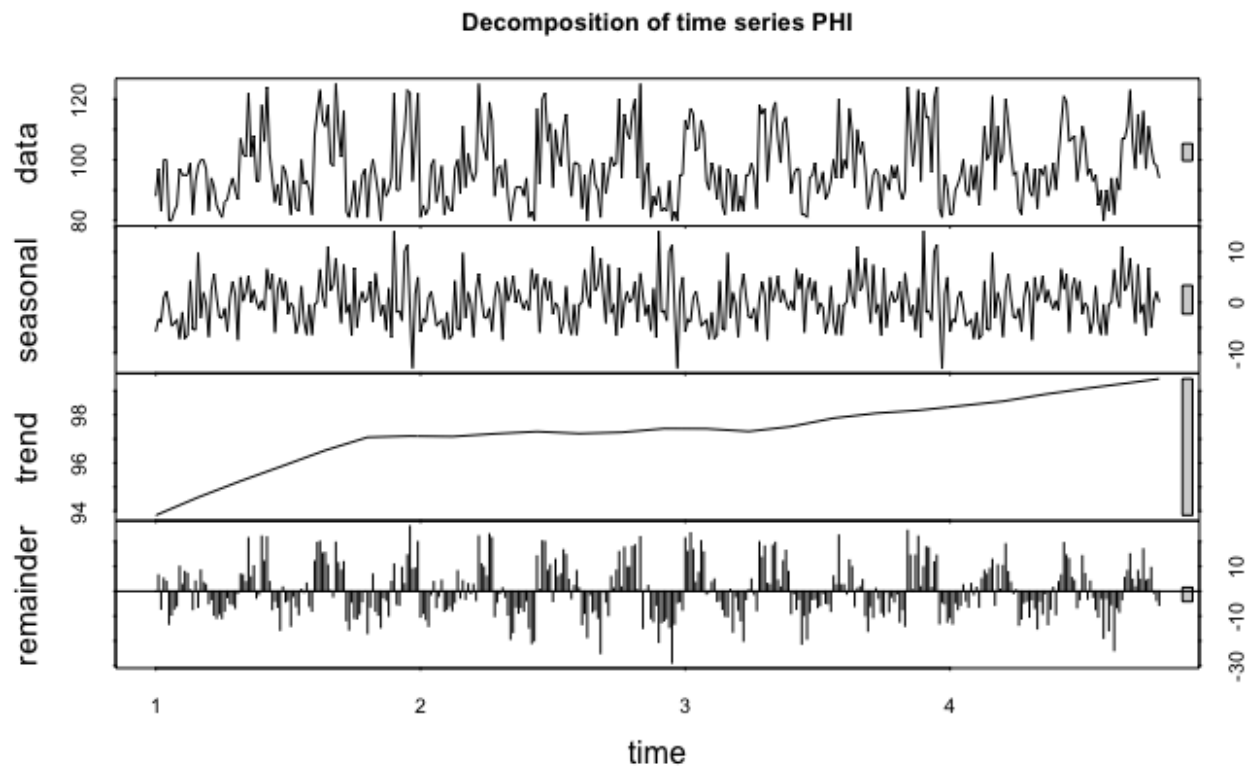

Gambar V.7 Analisis dekomposisi data TDS di lokasi PHI

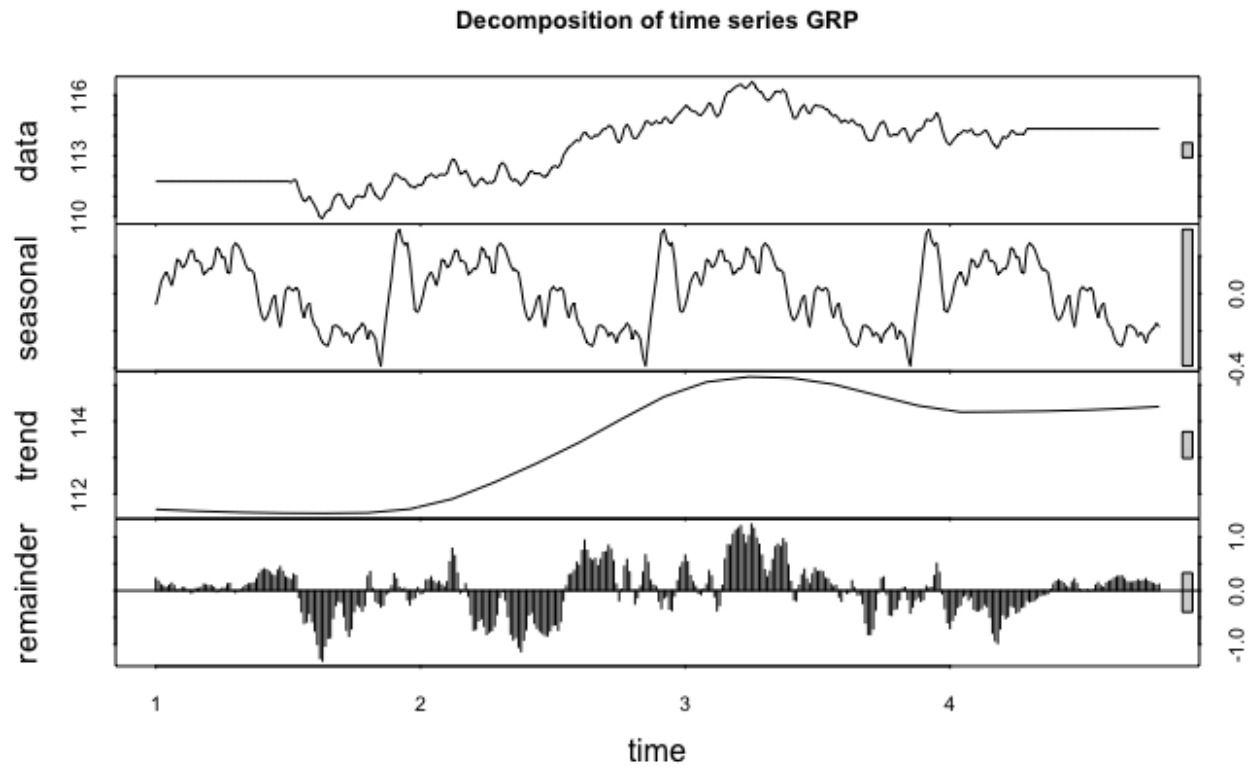

Gambar V.8 Analisis dekomposisi data TDS di lokasi GRP

pemukiman dapat dilihat dalam repositori proyek ini. Peta analisis untuk ketiga lokasi dapat dilihat pada Gambar V.9.

\section{V.0.3 Analisis multivariabel}

Hasil analisis multivariabel PCA dan CA dapat dilihat pada (Gambar V.10, Gambar V.11, Gambar V.13, dan Gambar V.12). Analisis ini menggambarkan pengelom- 


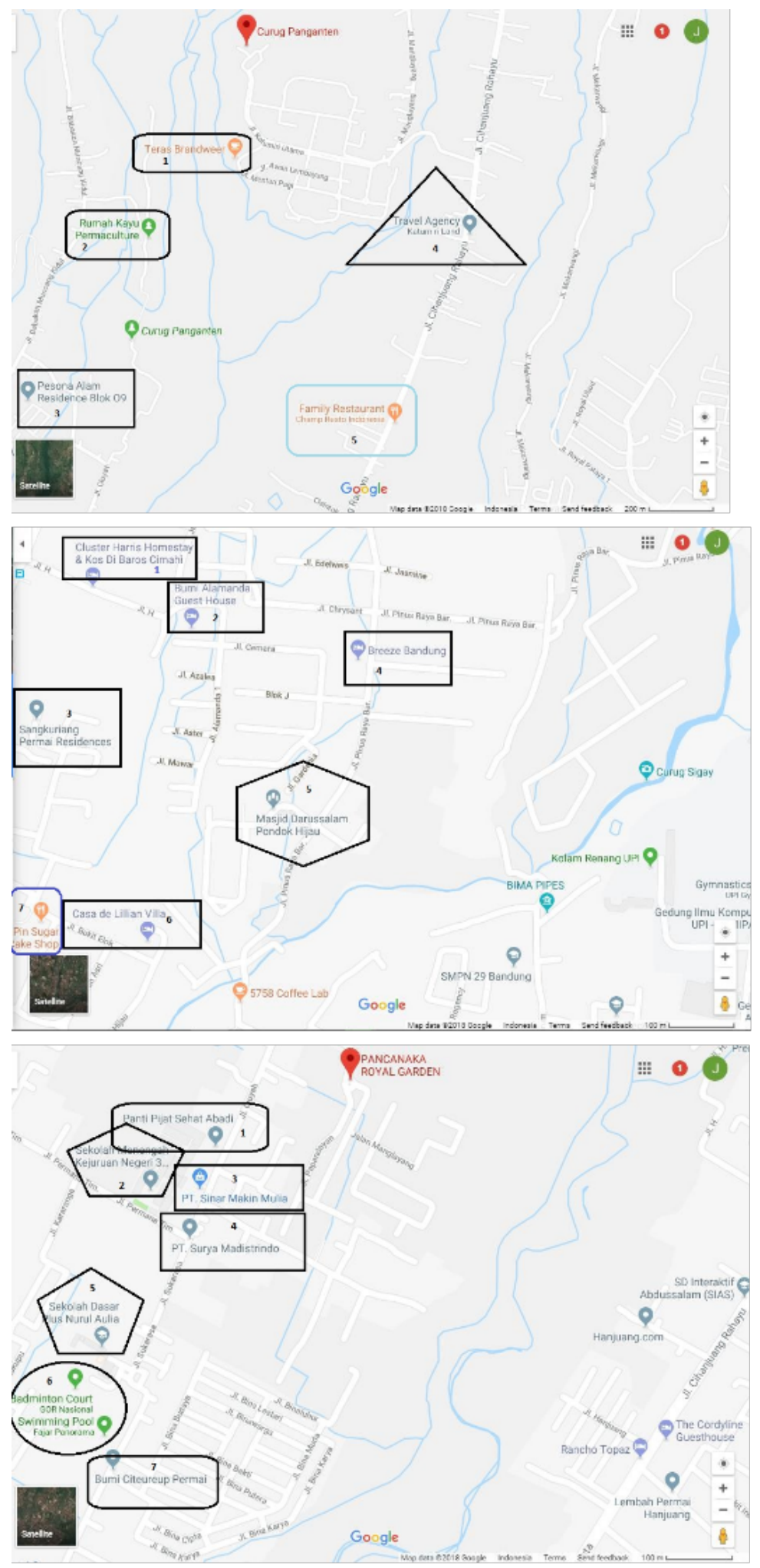

Gambar V.9 Analisis aktivitas obyek wisata dan perekonomian di lokasi CP (atas), PHI (tengah), dan GRP (bawah) 
pokkan data kualitas air tanah dan air sungai ke dalam empat kuadran (searah dengan jarum jam dimulai dari kuadran kiri atas). Gambar V.10 memperlihatkan adanya pemisahan variabel ke dalam bentuk komponen prinsipal (principan component/PC). Variabel yang berhubungan dengan hujan (cum rain dan lag rain), ketinggian (elv), potensial redoks (eh), spesies karbon $\left(\mathrm{CO}_{2}\right.$ dan $\left.\mathrm{CO}_{3}\right)$, dan klorin (Cl) berada di bagian bawah (Kuadran 3 dan 4). Variabel lainnya: spesies nitrogen $\left(\mathrm{NO}_{2}\right.$ dan $\mathrm{NO}_{3}$ ), tujuh ion utama, $\mathrm{pH}$, kesadahan (hard), $\mathrm{SiO}_{2}$, konduktivitas (ec), zat padat terlarut ( $\mathrm{tds}$ ), dan unsur logam Besi $(\mathrm{Fe}$ ) dan Mangan ( $\mathrm{Mn}$ ) berada di bagian atas (Kuadran 1 dan 2).

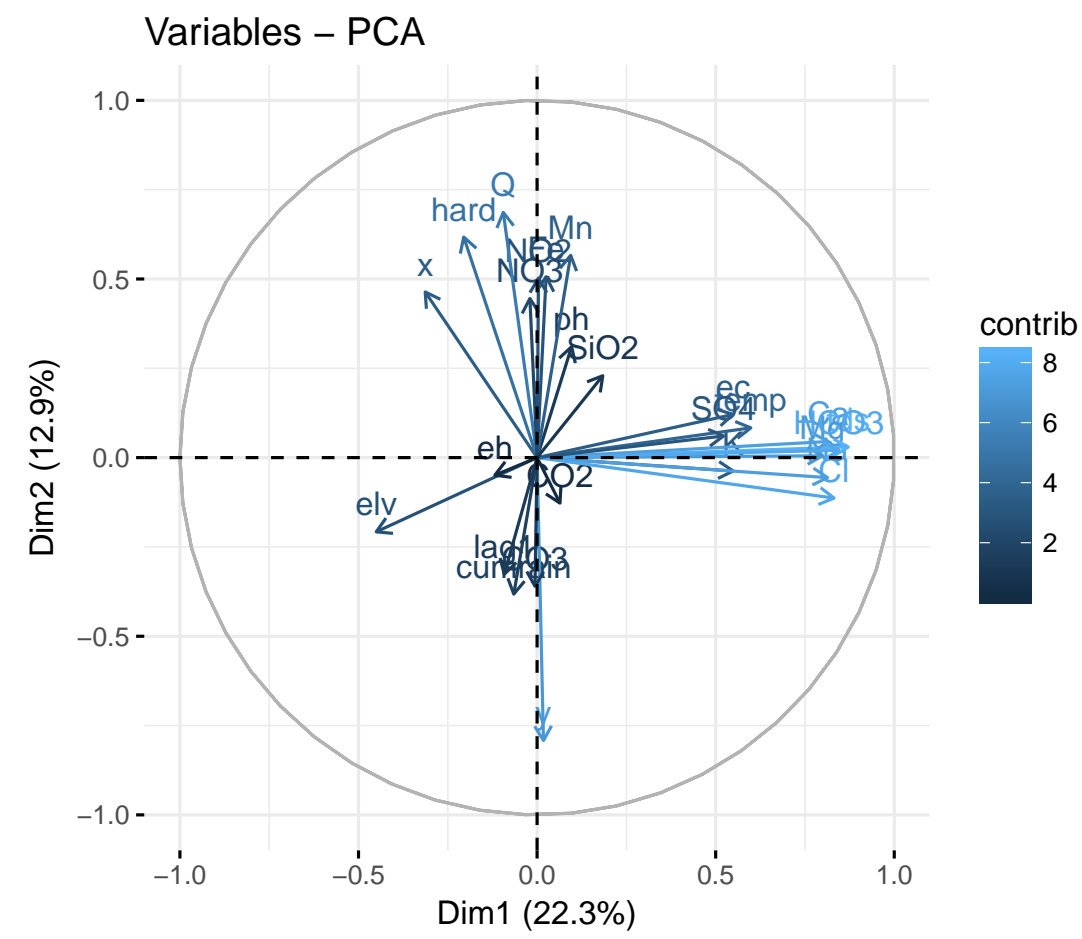

Gambar V.10 Nilai variabel terhadap komponen prinsipal (Loading PCA)

Berdasarkan posisi variabel terhadap sumbu PC di atas, kemudian diproyeksikan masing-masing titik data relatif berdasarkan komponen PC 1 dan PC 2 nya. Gambar V.11 memperlihatkan plot titik-titik sampel air sungai (hijau) dan air tanah (merah) ke dalam empat kuadran (1,2,3,4 searah jarum jam). Di sini kita dapat melihat posisi mayoritas titik sampel air tanah yang mengikuti sumbu $\mathrm{x}$ dan sedikit sampel air tanah mengikuti sumbu y. Sampel air sungai sendiri mayoritas ada di Kuadran 1. Secara umum, ini memperlihatkan bahwa karakter air sungai mirip dengan air tanah. Lebih jauh mengenai sampel air tanah. Mayoritas sampel air yang mengikuti sumbu $\mathrm{x}$ berasal dari akuifer tak tertekan (unconfined aquifer) endapan 
gunung api. Berdasarkan geografi, sampel yang berada jauh dari titik perpotongan sumbu berasal dari kawasan yang lebih tinggi, kemudian elevasinya makin rendah mendekati titik pusat perpotongan sumbu.

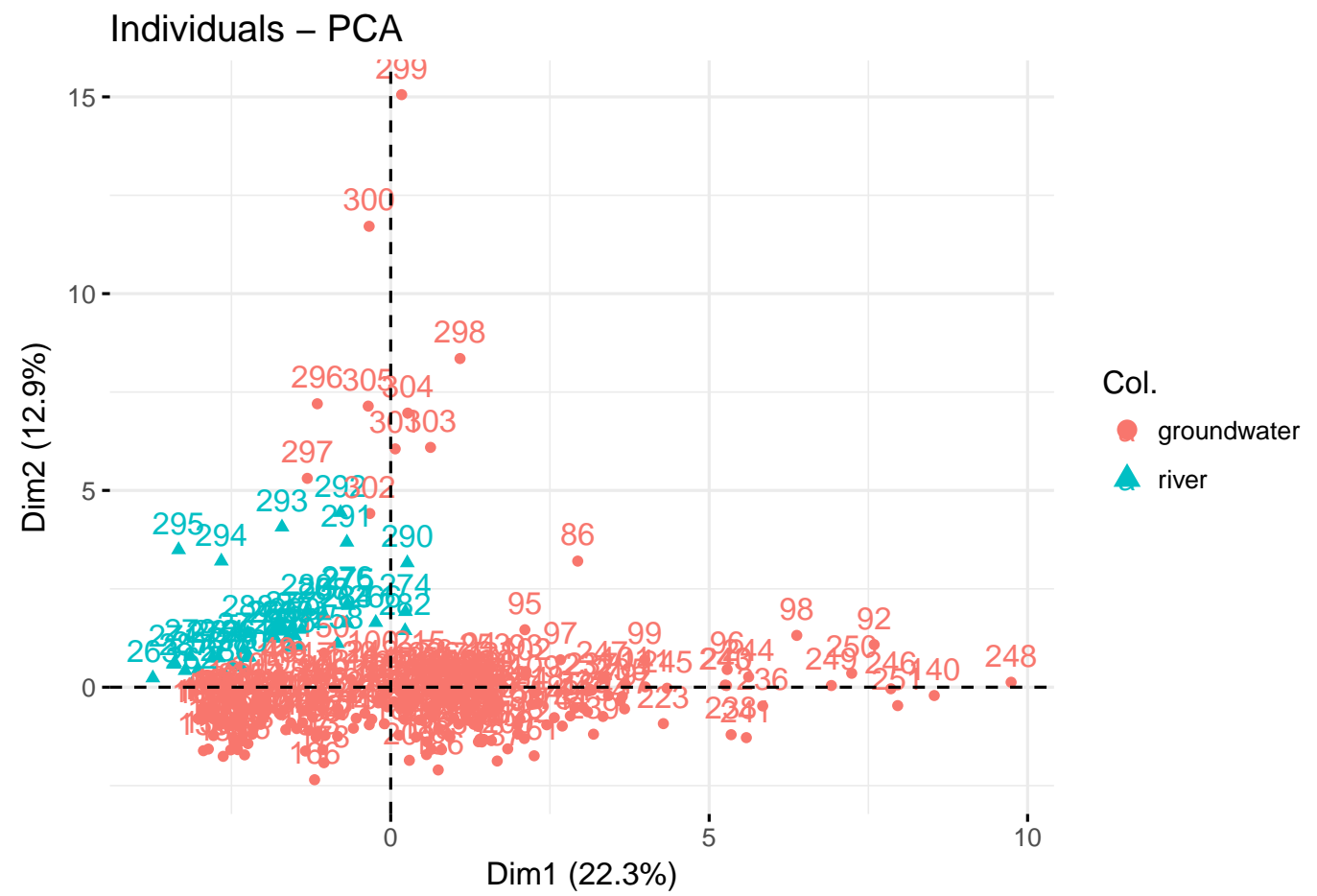

Gambar V.11 Posisi sampel terhadap komponen prinsipal (Scores PCA) (Merah=airtanah, biru=air sungai)

Klasifikasi sampel air pada Gambar V.11 lebih jelas ditunjukkan oleh Gambar V.13. Jumlah tiga klaster ditentukan oleh Gambar V.12. Di sini kita dapat melihat bahwa sampel air sungai (warna biru pada Gambar V.11) berada dalam klaster yang sama dengan sekelompok sampel air tanah, sebagaimana ditunjukkan dengan warna kuning pada Gambar V.13. Sampel air tanah dari kawasan selatan (akuifer lempungpasir), yang berada di bagian atas plot dalam Gambar V.11, kini dikelompokkan sebagai klaster baru. Dari sini dapat diinterpretasikan, bahwa karakter air tanah di bagian selatan Kota Bandung - kawasan Antapani, Ujung Berung, Gedebage, dan mungkin juga kawasan di sekitarnya - berbeda dengan karakter air tanah dari beberapa kawasan lainnya. Kondisi ini akan menarik bila ditelaah lebih rinci pada kesempatan berikutnya. Data-data ini dapat dikelompokkan berdasarkan kecamatan bila diperlukan, untuk dapat memperlihatkan karakter air tanah dalam konteks adminstrasi. 


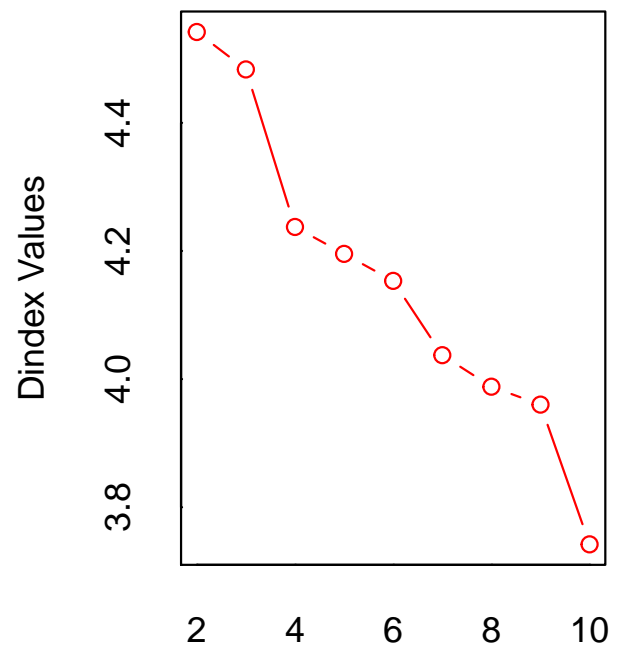

Number of clusters

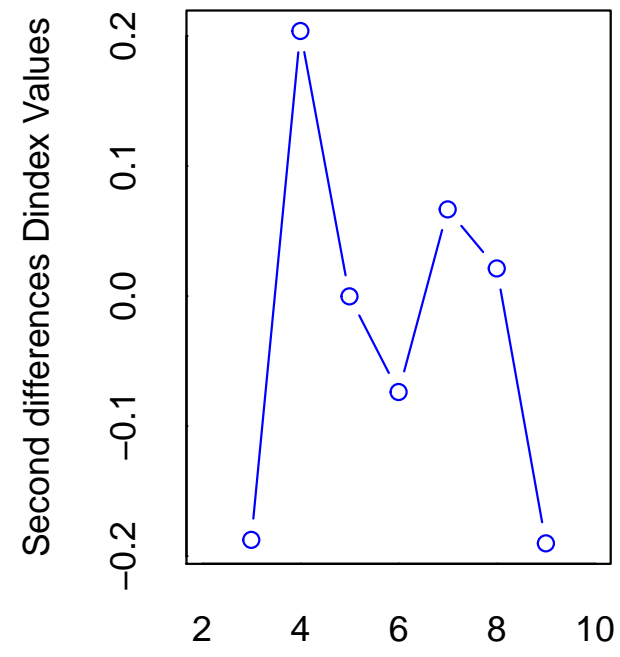

Number of clusters

Gambar V.12 Jumlah klaster optimal berdasarkan metode Kmeans

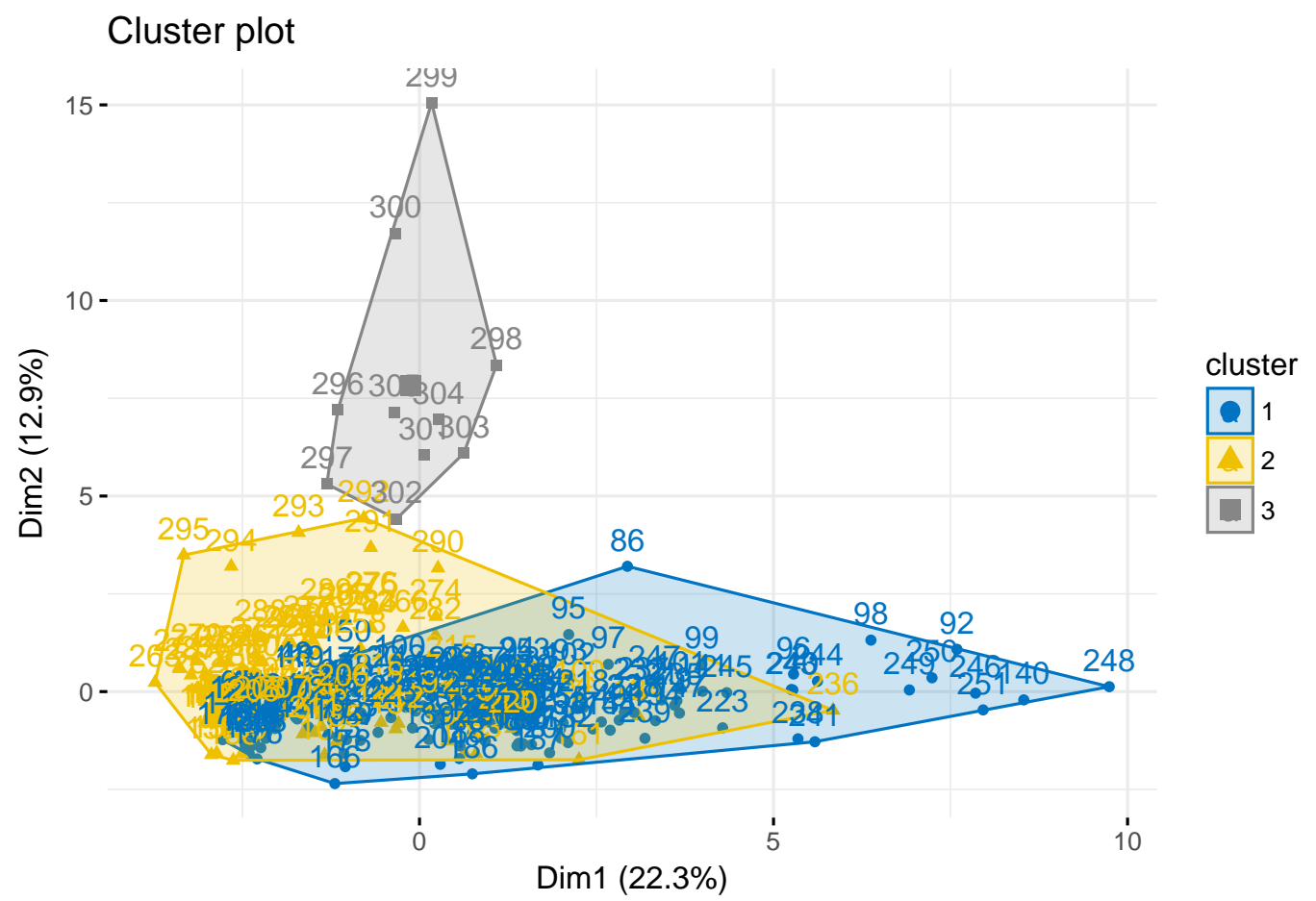

Gambar V.13 Penggolongan sampel menggunakan klaster metode Kmeans 


\section{Bab VI KESIMPULAN DAN SARAN}

\section{VI.0.1 Kesimpulan}

\section{Umum}

Riset ini menunjukkan bahwa riset berjenis eksploratori selalu menarik untuk dilaksanakan. Dalam konteks ini, kami mengeksplorasi interaksi antara kualitas air sungai dengan ekosistem dan aktivitas manusia. Korelasinya belum sepenuhnya kami pahami, tapi indikasi-indikasi yang dihasilkan dari riset ini adalah hal baru dan belum pernah diungkap oleh riset-riset atau artikel-artikel sebelumnya.

Analisis meta data atau sering juga disebut meta analysis dapat digunakan untuk memetakan posisi dalam konteks riset global. Analisis tersebut juga memaksimumkan pemanfaatan basis data Scopus yang dilanggan oleh ITB.

\section{Khusus}

Variasi harian data kualitas air dapat dianalisis untuk mengetahui proses yang terjadi pada air sungai itu sendiri juga interaksinya dengan air tanah, khusus pada zona hyporheic. Observasi dilakukan di tiga lokasi anak Sungai Cikapundung di tahun 2017 (periode Maret-November 2017). Pengukuran dilakukan pada tiga lokasi di DAS S. Cikapundung (diurutkan dari utara-selatan): S. Ciawitali lokasi Curug Panganten (CP) dan Grand Royal Pancanaka (GRP), S. Cibeureum lokasi Pondok Hijau Indah (PHI). Tata guna lahan berevolusi dari lahan terbuka berupa hutan dan lahan perkebunan/pertanian di lokasi CP dan GRP, ke perumahan di PHI. Sungai di ketiga lokasi itu menjadi muara dari saluran-saluran air yang melewati kawasan di tepi kiri dan kanannya.

Pengukuran debit (meter/detik), temperatur air sungai (derajat Celcius), temperatur udara (derajat Celcius), dan TDS (total dissolved solids) (ppm). Pengukuran dilakukan dengan alat portabel merk Lutron, masing-masing dengan ketelitian 0.01 pada masing-masing satuan yang berkaitan. Pengukuran dilakukan empat kali di masing-masing lokasi: pukul 10.00, 12.00, 14.00, dan 16.00. Data kemudian dianalisis menggunakan piranti lunak open source $\mathrm{R}$ untuk teknik time series.

Hasil pengukuran di ketiga lokasi tersebut menunjukkan variasi mingguan dan bulanan. Untuk variasi minggu, nilai TDS naik mulai hari Jumat dan turun pada hari Senin. Lokasi yang paling konsisten menunjukkan gejala ini adalah PHI. Variasi bulanan menunjukkan peningkatan di bulan Juni dan turun di bulan Juli. 
Pola ini terjadi di tiga lokasi tersebut. Pada titik ini, kami berpendapat bahwa pola tersebut diduga berkaitan dengan aktivitas manusia yang meningkat di akhir minggu. Untuk pola bulanan, ada indikasi bahwa peningkatan TDS bersamaan dengan liburan Lebaran 2017.

Hasil analisis multivariabel memperlihatkan bahwa telah terjadi pencampuran (mixing) antara air tanah dan air sungai, khususnya di bantaran S. Cikapundung. Hal ini memperkuat dugaan bahwa kenaikan nilai TDS karena kondisi efluen dapat terjadi sebelumnya, sehingga nilai TDSnya sungai akan bervariasi. Namun peningkatan yang signifikan terjadi karena pembuangan limbah di sepanjang bantaran sungai.

\section{VI.0.2 Saran}

Dugaan-dugaan yang muncul dari riset ini perlu diklarifikasi lebih lanjut dengan pengukuran kandungan nutrien (nitrat, nitrit, fosfat, klorin, dan sulfat). Kami menyarankan kepada para penelaah untuk menggunakan data time series guna mengetahui kondisi fisik yang mungkin dapat diurai dari angka-angka yang terekam pada alat. Dari riset ini, dapat kami sampaikan bahwa data time series sangat berperan dalam analisis lingkungan, sehingga layak untuk dikembangkan.

Pengembangan tidak terbatas pada teknik analisis time series, tetapi juga machine learning yang utamanya dapat digunakan untuk mengklasifikasikan data dengan variabel pengukuran yang sangat banyak. Teknik machine learning ini sudah beberapa kali digunakan untuk tesis atau disertasi hidrogeologi dengan tema pemodelan. Penggunaannya dapat diperluas, tidak hanya untuk pemodelan spasial. 


\section{DAFTAR PUSTAKA}

Astuti, M. D. (2013): Faktor penghambat masyarakat dalam mengubah orientasi bermukim ke sungai (studi kasus: Kec. Dayeuhkolot, Kab. Bandung), Reka Loka, 1(1).

Bo, L. (2013), : Introduction to Time Series. (Accessed on 03/16/2018).

URL: http://www.stat.purdue.edu/boli/stat420/lectures/lecture 1.pdf

ColumbiaUniversity (2017), : Generalized Linear Models. (Accessed on 02/25/2018).

URL: $h t t p: / / w w w . s t a t . c o l u m b i a . e d u / \operatorname{martin} / W 2024 / R 11 . p d f$

Commons, W. (2014), : Data visualization process and exploratory research Wikimedia Commons. (Accessed on 03/13/2018).

URL: $h t t p s: / / g o o . g l / m g 6 Z u 3$

Creative Commons Attribution 4.0 International $C C \quad B Y 4.0$ (n.d.), https://creativecommons.org/licenses/by/4.0/. Accessed on Mon, February 19, 2018.

URL: https://creativecommons.org/licenses/by/4.0/

Darul, A., Irawan, D. E., Trilaksono, N. J., Pratama, A. and Fitria, U. R. (2016), Conceptual model of groundwater and river water interactions in Cikapundung riverbank, Bandung, West Java, dalam IOP Conference Series: Earth and Environmental Science, Vol. 29, IOP Publishing, 012026.

URL: http://iopscience.iop.org/article/10.1088/1755-1315/29/1/012026/pdf

Gio, P. U. (2018), : Time Series dengan K-Stat Kalkulator Statistika (K-Stat). (Accessed on 03/16/2018).

URL: https://kalkulatorstatistika.com/2018/01/14/time-series-dengan-k-stat/

HarvardUniversity (2017), : Linear regression tutorials. (Accessed on 02/25/2018).

URL: http://tutorials.iq.harvard.edu/R/Rstatistics/Rstatistics.html

Hayashi, M. (2004): Temperature-electrical conductivity relation of water for environmental monitoring and geophysical data inversion, Environmental monitoring and assessment, 96(1-3), 119-128.

Hyndman, R. J. (2017): forecast: Forecasting functions for time series and linear models. $\mathrm{R}$ package version 8.2.

URL: http://pkg.robjhyndman.com/forecast

Hyndman, R. J. and Khandakar, Y. (2008): Automatic time series forecasting: the forecast package for R, Journal of Statistical Software, 26(3), 1-22.

URL: http://www.jstatsoft.org/article/view/v027i03

io, A. (2015), : Extract Seasonal \& Trend: using decomposition in R - Anomaly. (Accessed on 03/13/2018).

URL: https://anomaly.io/seasonal-trend-decomposition-in-r/

Irawan, D. E. (2017): The Hydrochemistry of Mt. Ciremai.

Irawan, D. E. and Aditya, S. (2018), : Variasi kualitas air sungai di Kawasan Cimahi dan Bandung Utara.

URL: $h t t p: / / o s f . i o / y q 72 n$

Irawan, D. E., Brahmantyo, B., Puradimaja, D. J., Priyono, I. and Darul, A. (2018a): Visual research landscape of surface water and groundwater interactions 
(1980-2017).

Irawan, D. E., Brahmantyo, B., Puradimaja, D. J., Priyono, I. and Darul, A. (2018b): Visual research landscape of surface water and groundwater interactions (1980-2017).

Irawan, D. E. and Furqon, A. J. (2017): Preliminary mapping: Ecohydrology of Cikapundung river, Bandung.

URL: https://osf.io/preprints/inarxiv/mdaqs/

Irawan, D. E., Puradimaja, D. J., Yeni, D., Kuntoro, A. A. and Julian, M. M. (2016): Decreasing groundwater quality at Cisadane riverbanks: groundwater-surface water approach, arXiv preprint arXiv:1603.09380, .

URL: https://arxiv.org/pdf/1603.09380

Liu, J., Zhang, X., Wu, B., Pan, G., Xu, J. and Wu, S. (2017): Spatial scale and seasonal dependence of land use impacts on riverine water quality in the Huai River basin, China, Environmental Science and Pollution Research, 24(26), 2099521010.

URL: https://doi.org/10.1007/s11356-017-9733-7

Marganingrum, D., Roosmini, D., Pradono, P. and Sabar, A. (2013): Diferensiasi Sumber Pencemar Sungai Menggunakan Pendekatan Metode Indeks Pencemaran (IP)(Studi Kasus: Hulu DAS Citarum), RISET Geologi dan Pertambangan, 23(1), 41-52.

Priyambada, I., wiharyanto Oktiawan and Suprapto, R. (2008): Analisa pengaruh perbedaan fungsi tata guna lahan terhadap beban cemaran BOD sungai (Studi kasus: Sungai Serayu - Jawa Tengah), Jurnal Presipitasi: Media Komunikasi dan Pengembangan Teknik Lingkungan, 5(2).

URL: https://ejournal.undip.ac.id/index.php/presipitasi/article/view/11012

Putra, D. S. and Putra, A. (2014): Analisis pencemaran limbah cair kelapa sawit berdasarkan kandungan logam, konduktivitas, TDS dan TSS, Jurnal Fisika Unand, . Accessed on 02/24/2018.

URL: http://jfu.fmipa.unand.ac.id/index.php/jfu/article/viewFile/92/74

R Core Team (2014), R: A Language and Environment for Statistical Computing, $\mathrm{R}$ Foundation for Statistical Computing, Vienna, Austria.

URL: http://www.R-project.org/

Raaijmakers, R., Krywkow, J. and van der Veen, A. (2008): Flood risk perceptions and spatial multi-criteria analysis: an exploratory research for hazard mitigation, Natural hazards, 46(3), 307-322.

Ramakrishnaiah, C., Sadashivaiah, C. and Ranganna, G. (2009): Assessment of water quality index for the groundwater in Tumkur Taluk, Karnataka State, India, Journal of Chemistry, 6(2), 523-530.

Ramdani, J., Septiana, F., Irawan, D. E. and Darul, A. (2017): Comparative petrographic analysis of volcanic rocks in five different areasa using" $\mathrm{R}$ ".

Rohmat, D. (2009): Solusi aspiratif penanganan masalah sungai mati (Kasus: Desa Andir Kecamatan Bale Endah Kabupaten Bandung), Jurnal Geografi Gea, 9(1).

Salim, A. G. and Dharmawan, I. W. S. (2017): Biologycal Oxygen Demand (BOD), Chemical Oxygen Demand (COD), Total Dissolved Solids (TDS) dan 
Total Suspended Solids (TSS) sungai-sungai di DAS Citarum bagian hulu. Pengambilan sampel dilakukan dengan metode Purposive sampling kemudian dianalisis kandungan BOD, COD, TDS dan TSS. Analisis data dilakukan secara tabulasi, grafik dan deskriptif, berdasarkan hasil analisis, Bunga rampai pengelolaan lahan dan air secara berkelanjutan, 49.

URL: https://goo.gl/yz9hpg

Tanuwijaya, Z. A., Hendarmawan, H., Sudrajat, A. and Kuntjoro, W. (2017): Anomali Imbuhan Pada Segmen Zona Transfer Sistem Fluvial Cikapundung, Jawa Barat, Bulletin of Scientific Contribution: GEOLOGY, 14(3), 295-302.

URL: http://journal.unpad.ac.id/bsc/article/view/10968

Texas A \& M University (2017), : GLM Tutorial in R. (Accessed on 02/25/2018).

URL: http://people.tamu.edu/ alawing/materials/ESSM689/GLMtutorial.pdf

TIER, P. (2014), : Project TIER - Teaching Integrity in Empirical Research. (Accessed on $03 / 13 / 2018$ ).

URL: https://www.projecttier.org/ 
Info cetak .....

Revisi/cetak terakhir: 24 November 2018, pukul 08:28

Nomor halaman: i-1, 1-33 Total: 45 halaman 